تأثير التحول الرقمي على القدرة التنافية والقيمة المضافة للقطاع السياحي

سماح عبد الحفيظ يوسف

مدرس، قسم الدراسات السياحية،

المعهد العالي للدراسات النوعية بالجيزة
نهلة عبد الوهاب عبد الصادق مشهور

مدرس، قمم الدراسات السياحية،

المعهد العالي للدراسات النوعية بالجيزة

الكلمات المفتاحية المقالة
على تتمية القطاع السياحي المصري من خلال إيجاد إطار مقترح للعلاقة التأثيرية

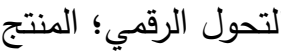
السياحي؛ القدرة التنافسية؛ بين التحول الرقمي وتطوير المنتج السياحي بهدف زيادة القدرة التنافسية والقيمة المضافة للقطاع السياحي. وقد اعتدت الدراسة على المنهج الوصفي بالإضافة

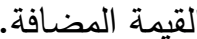
إلى المنهج الاستنباطي: حيث تم استخدام المسح الميداني في اشتقاق عناصر

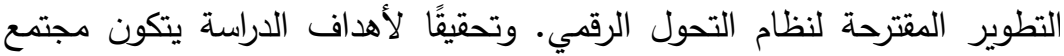

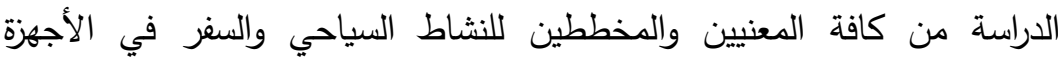
السياحية الحكومية، ومديري التسويق والسياحة في شركات السياحة، وكذلك بعض التض

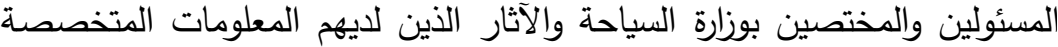
عن موضوع الدراسة، بالإضافة إلى الخبراء المختصين في مجال تكنولوجيا المعلومات والاتصالات. فقد تم اختيار عينة عشوائية بسيطة من مجتمع الدراسة

(JAAUTH)

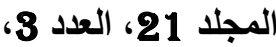

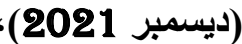

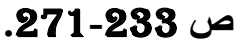
بلغت (150) مفردة، وقد استخدم استبيان لجمع البيانات من أفراد عينة الدراسة، وقد اظهرت النتائج أن غالبية الآراء ترى وجود أهمية لتوافر البنية الأساسية

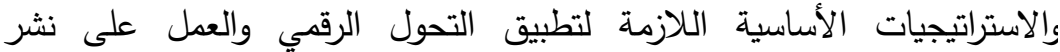
الخدمات الرقمية المستهدفة في المؤسسات السياحية بالإضافة إلى أهمية العمل على إزالة الصعوبات التي تواجه تطبيق التحول الرقمي في قطاع السياحة المصرية وتطوير المنتج السياحي المصري.

1 - المقدمة

تواجه المؤسسات والثركات السياحية تحديات كبيرة في ظل التطورات المتسارعة لتكنولوجيا المعلومات والاتصالات، من أبرزها التحول الرقمي وانتشار التتنيات الرقمية ومسايرة التطورات التكنولوجية الحديثة في هذات فئات

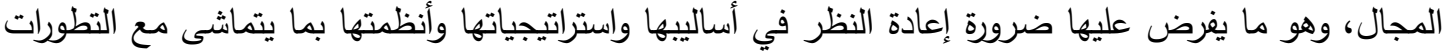

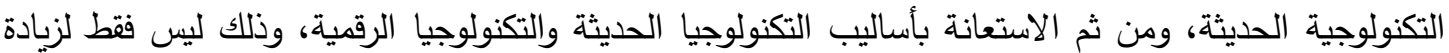
قدرتها التنافسية، وإنما لضمان بقائها واستمرارها في السوق.

وفي هذا الإطار تعتبر التكنولوجيا الرقمية والتحول الرقمي كأحد التطبيقات للأساليب التكنولوجية الحديثة والتي ظهرت في الآونة الأخيرة من أهم التحديات التي تواجه شركات السياحة المصرية، فقد دعت الهنظمة العربية 
لللياحة (2021) العالم العربي لأهية التحول الرقمي لكافة الخدمات السياحية المقدمة وخاصة في ظل تداعيات جائحة فيروس كورونا المستجد (COVID-19) على قطاعات السياحة وخطوات التعافي المستقبلية.

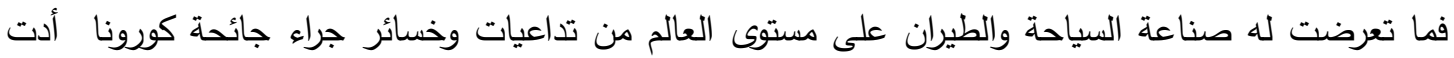

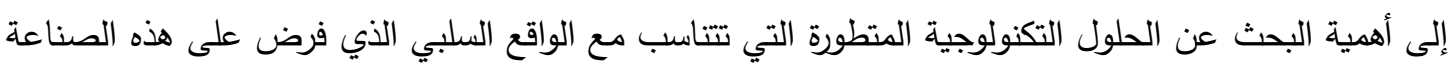

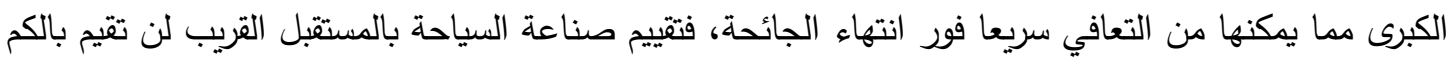

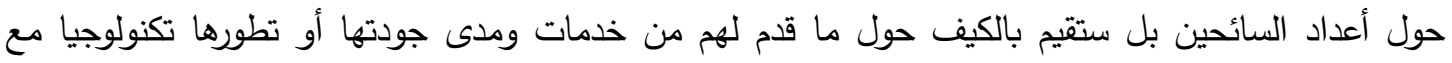

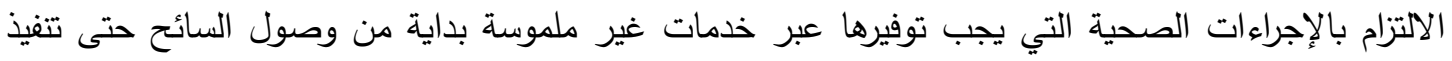

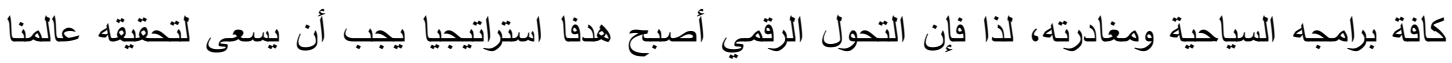
العربي ليكون بصاف الدول المتقدمة بهذه الصناعة الكبرى ليحظى بما يستحقه من خلال عودة للسياحة الآمنة. وسوف يقابل ذلك خلق فرص عمل جديدة تعتمد على مهارات العصر الرقمي الجديد.

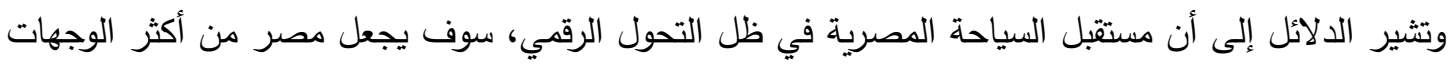

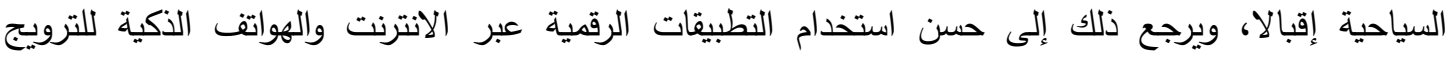

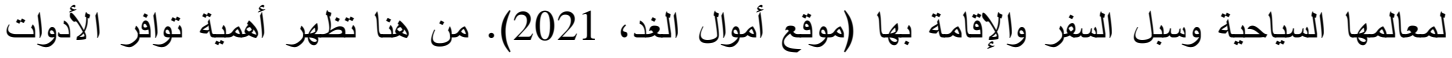

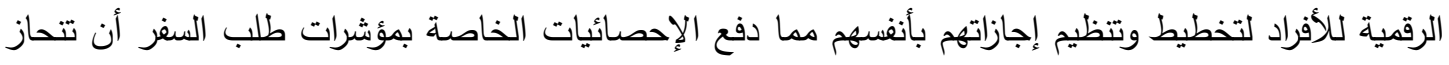

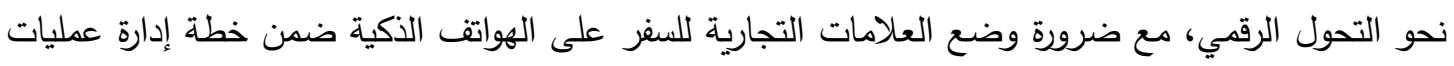
الحجز لرحلات الطيران وغرف الفنادق حول العالم واتجاه المسافرين لحجز وجهاتهم عبر تلك التطبيقات، فقضاء

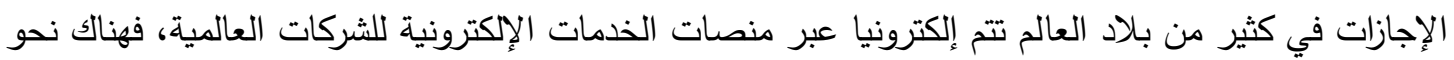

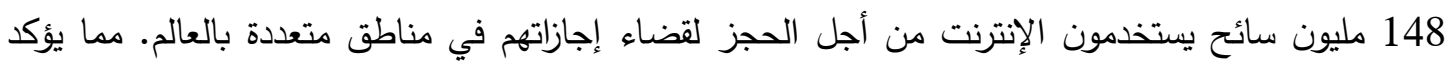

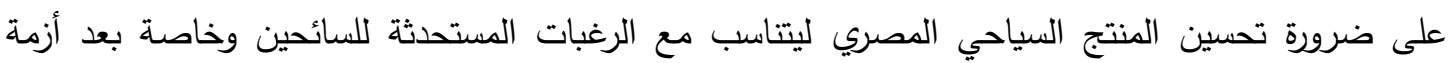

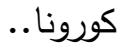

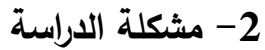

يتطلب انتثار الثقافة الرقمية في المؤسسات السياحية إحداث تغيير جذري في أسلوب إدارة هذه المؤسسات والثركات، حيث يستلزم تطبيق التقنيات الرقمية المتطورة كأساس عمل لكل عناصر المؤسسة من دعم اتخاذ

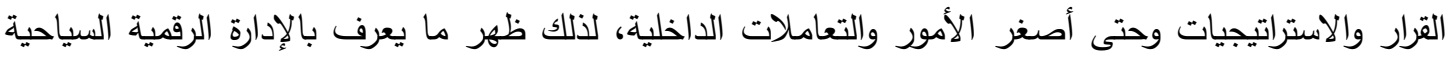

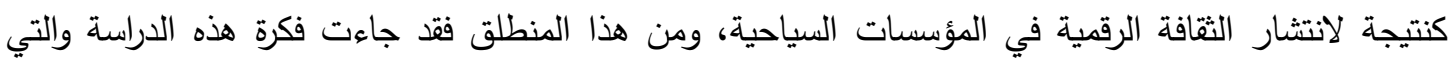
تهدف إلى التعرف على دور التحول الرقمي وأثره على تتمية القطاع السياحي المصري من خلال التساؤلات

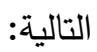
1. ما دور الثقافة الرقمية في تتمية وتتثيط القطاع السياحي المصري في ظل التحولات المتسارعة في

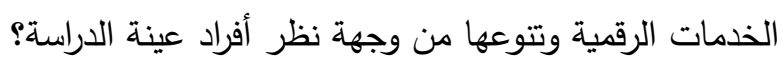
2. ما القيمة المضافة لتكنولوجيا المعلومات والاتصالات في قطاع السياحة؟ 
3. ما معوقات تتفيذ التحول الرقمي في القطاع السياحي المصري من وجهة نظر أفراد عينة الدراسة؟

$$
\text { 3- أهمية الاراسة }
$$

يشتق البحث أهميته العلمية والعملية من أهمية أنظمة التسويق الإكتروني لثركات السياحة والسفر، وكذلك من

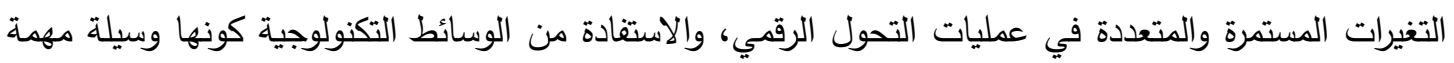

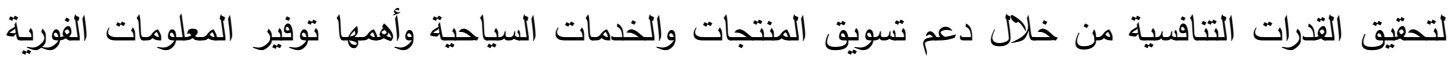

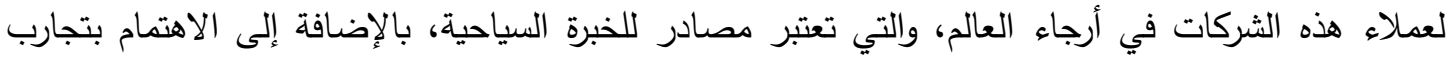

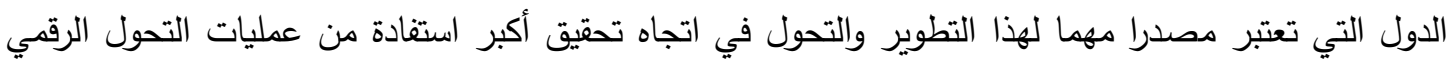
المتسارع.

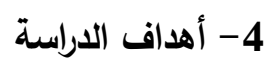

1. تهدف هذه الدراسة إلى إبراز أهمية تأثير التحول الرقمي على تطوير المنتج السياحي وأثره على تتمية

$$
\text { القطاع السياحي المصري. }
$$

2. تساهم الدراسة في محاولة إيجاد نموذج مقترح لاعم وتطوير المنتج السياحي في ضوء التحول الرقمي وأثره على زيادة القدرة التنافسية والقيمة الدضافة للقطاع السياحي.

5- الفرضية الرئيسية للاراسة اعتمدت الدراسة على فرضية أساسية مفادها "لا توجد علاقة بين تطوير ودعم المنتج السياحي وبين التحول الرقمي"، وسوف يتم تقسيم هذه الفرضية إلى فروض فرعية داخل الدراسة الميدانية طبقا لبنود قائمة الاستقصاء.

\section{6- 6 - منهجية الاراسة}

يستند البحث إلى الدنهجين التاليين: أ- - المنهج الوصفي: اعتمدت هذه الدراسة على المنهج الوصفي التحليلي، ومن خلاله يتم إزالة الغموض عن بعض المفاهيم التي تتعلق بعمليات التحول الرقمي ودعم ذلك من خلال تناول بعض الدراسات السابقة

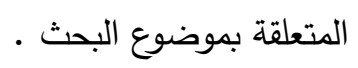

ب- المنهج الاستتباطي: تم استخدام أسلوب البحث الميداني في اشتقاق عناصر التطوير المقترحة لنظام التحول

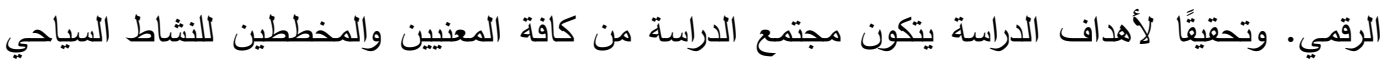
والسفر بالأجزة السياحية الحكومية ومديري التسويق في شركات السياحة، وكذلك بعض المسئولين

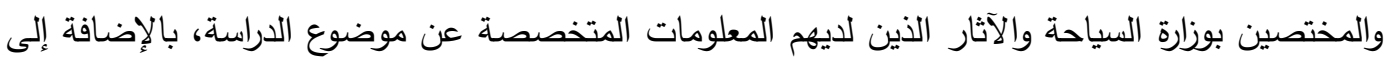

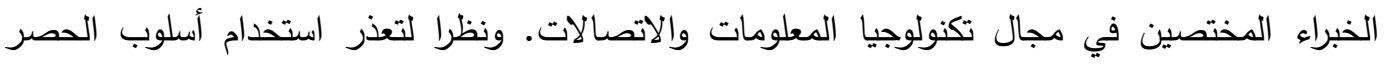

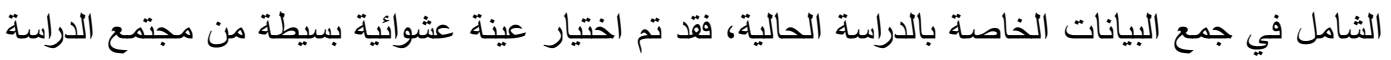

$$
\text { بلغت (150) مفردة. }
$$


7- الإطار النظري والدراسات السابقة

أولا: الإطار النظري الإطار النظري

تعد الثورة الرقمية إحدى أبرز تجليات التطور التكنولوجي الذي يشهده علمنا اليوم، حيث اجتاحت الطفرة

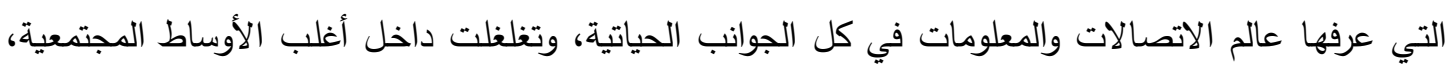

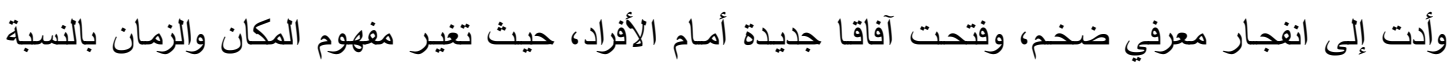

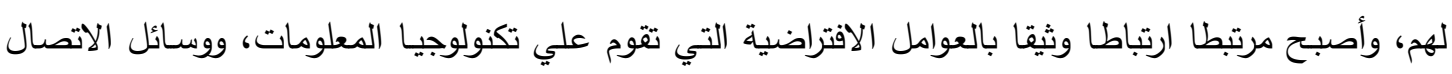
الحديثة (Labanauskaitėa,2020).

$$
\text { 1- مفهوم التحول الرقمي }
$$

عرف (Brysch, A. 2019) التحول الرقمي بأنه: استخدام التقنيات الرقمية الحديثة لتغيير نموذج الأعمال

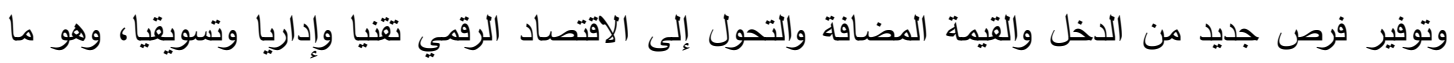

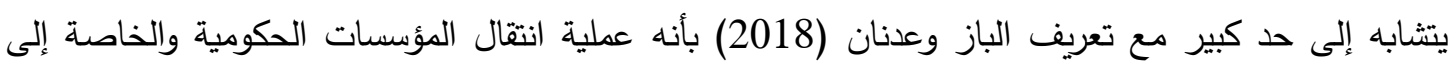

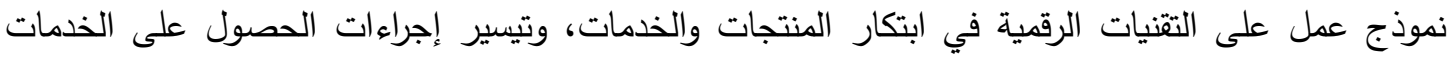
الدقدمة للعملاء من خلال الاعتماد على الخدمات المبتكرة والإبداعية.

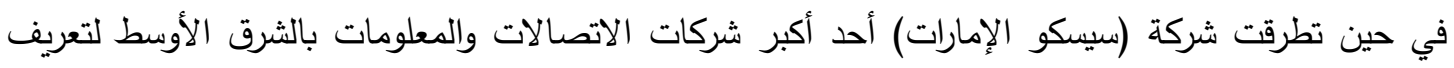

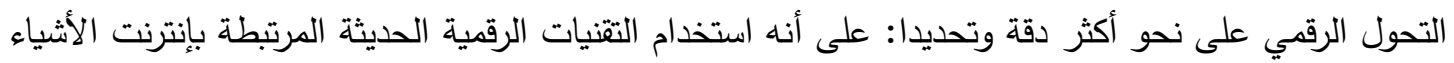

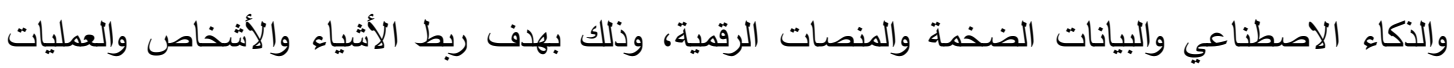

$$
\text { والبيانات معا (دبوسي وربيع، 2015). }
$$

ويوصف التحول الرقمي أيضا بأنه تحول أنشطة الأعمال والخدمات والعمليات والكفاءات إلى نماذج رقمية ذات

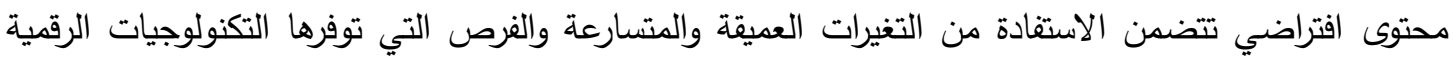

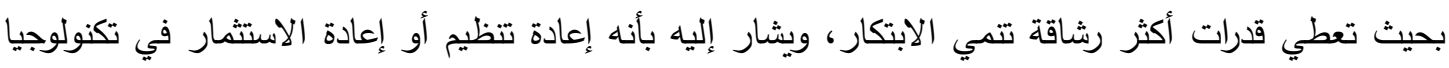

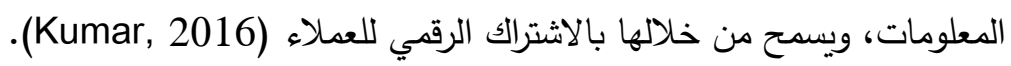

ومن هنا يمكن تعريف التحول الرقمي بأنه "الانتقال من نظام تقليدي إلى نظام رقمي قائم على تكنولوجيا

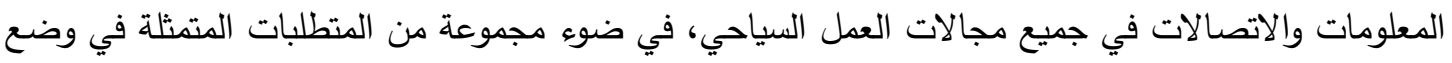

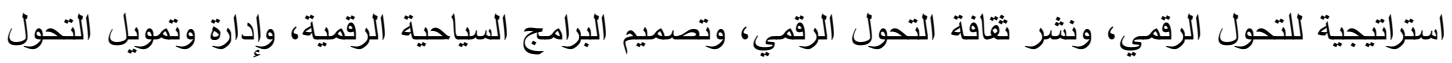
الرقمي، بالإضافة إلى المتطلبات البشرية، والتقنية، والأمنية، والتثريعية.

وتستثيد من هذه التكنولوجيا جميع مجالات الأعمال التجارية والخدمية ولاسيما قطاع السياحة، فتجربة السفر

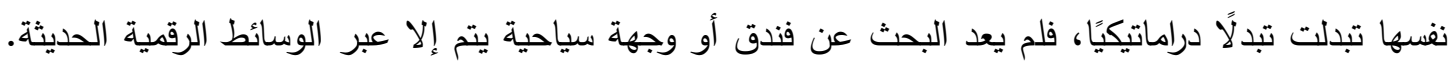

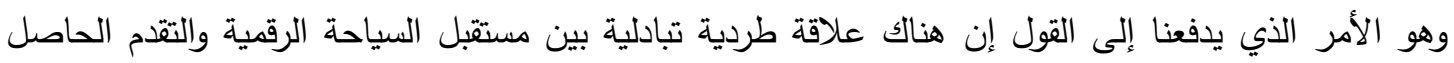

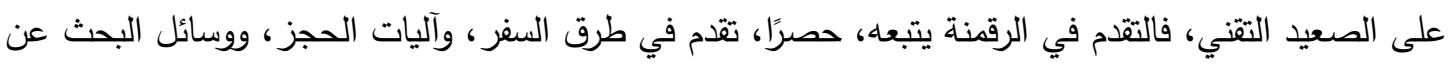
الوجهات والsقاصد السياحية الدختلفة (محمد علواني، 2020). 
ومن هنا يتضح أن مستقبل السياحة الرقمية مرهون بفهم القائمين عليها لذهنية وعقلية الثريحة الأكبر من

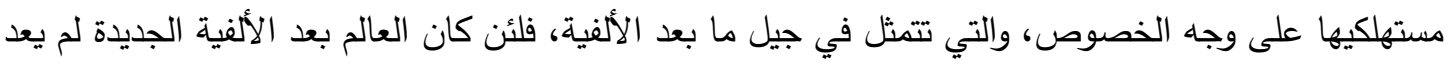

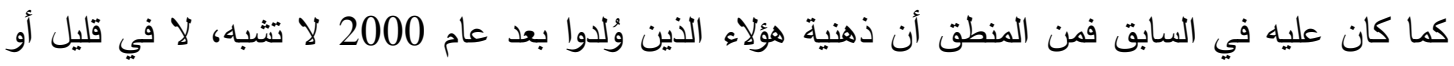

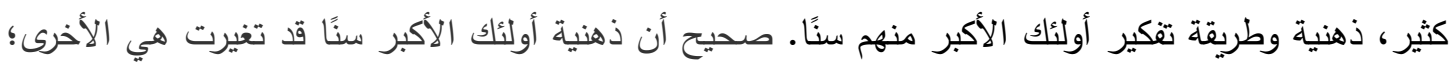

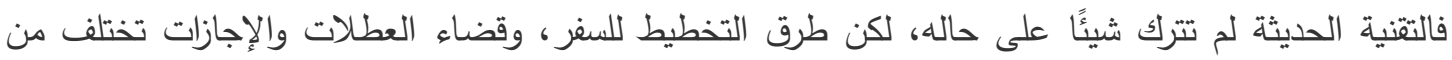

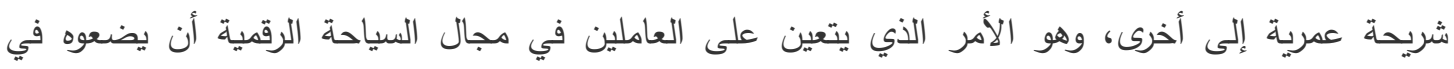

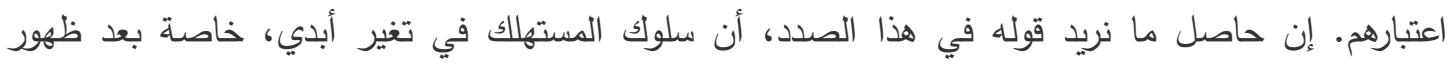

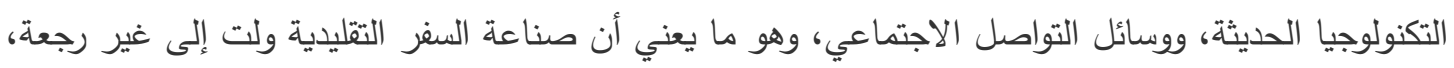
هذا من جهة، ومن جهة أخرى، يتعين أن نرسم، وفقًا لسلوك المستهلك الجديد، معالم مستقبل السياحة الرقمية. 2- ت ت تامي المستهلك الرقمي من المنطقي أن يؤثر هذا التحول الرقمي في سلوك المستهلكين، وهو أمر بات واقعًا وحقيقة؛ إذ لكل خدمة

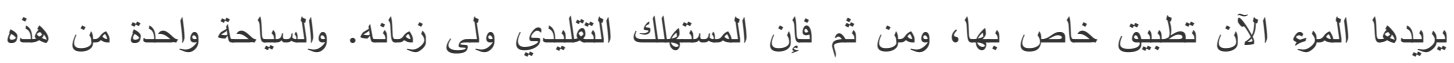

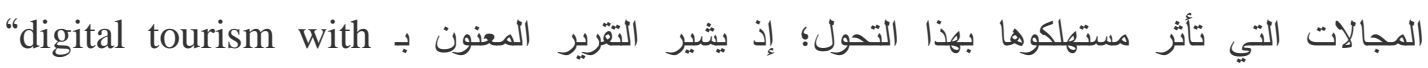
limmersive technology”

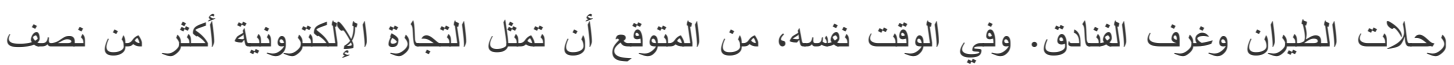
التجارة بحلول عام 2021. وعلى ذلك، فإن الحديث عن مستقبل السياحة الرقمية هو، وبالقدر ذاته، حديث عن التهن

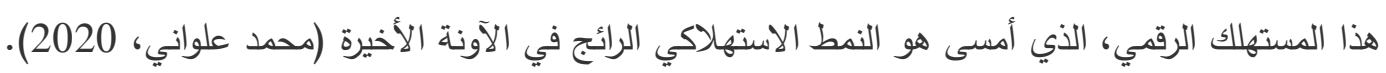

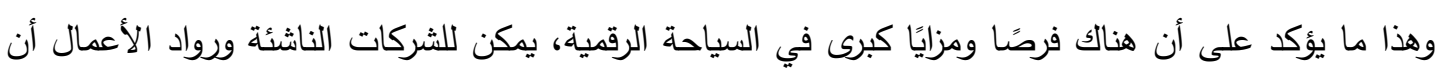

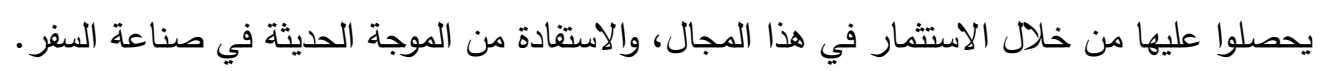

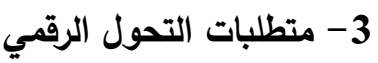

يرى شعلان (2017) أن عملية التحول الرقمي يجب أن تتضمن ثلاثة متطلبات رئيسة، أولها: تحديد

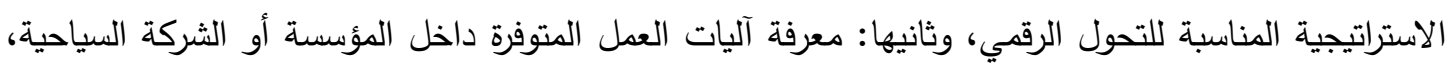

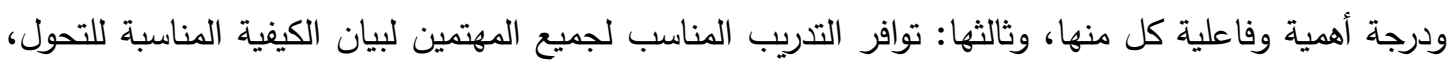

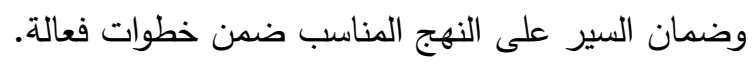
يستلزم تطبيق التحول الرقمي توافر كل من التتنيات والبيانات والموارد البشرية والعمليات في القطاعين العام

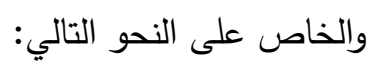

أ- التتنيات: ويقصد بها توفير الدنلبات التكنولوجية لبناء التحول الرقمي باستخدام منظومة من الأجهزة

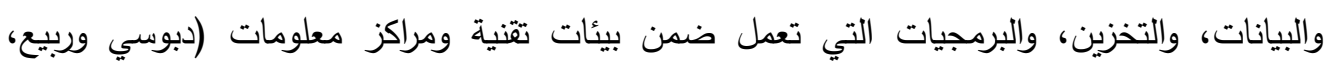

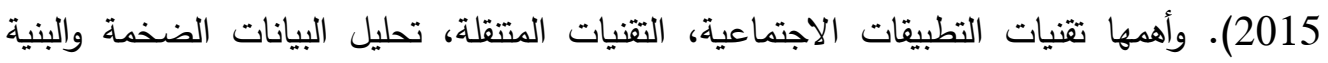


Cloud ( التحتية للحوسبة السحابية (دورو وايمانويل، 2019). وعبر مصطلح الحوسبة السحابية (Computing

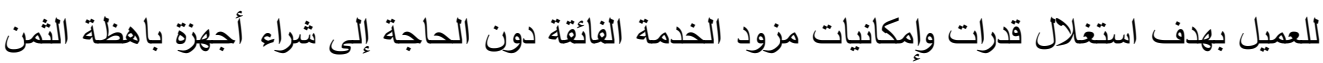

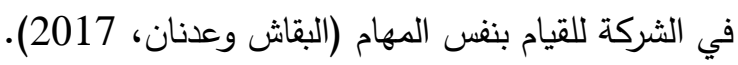
ب- البيانات: تتضمن قيام المؤسسات بإدارة وتحليل البيانات بشكل منظظم وفعال، وذلك لتوفير بيانات

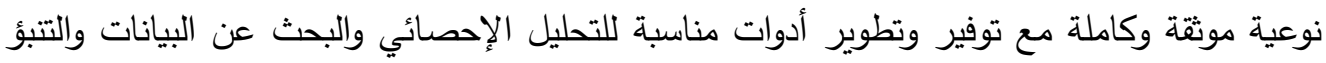

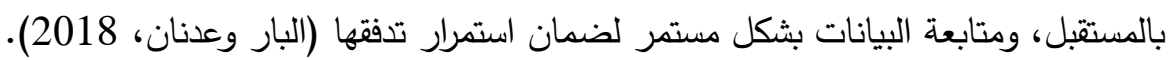

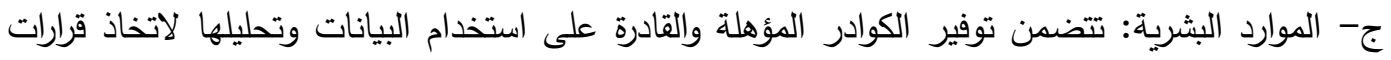
فعالة وتتفيذها، وأن تكون مدربة وفق أحدث أنظمة التكنولوجيا الرقمية وذات خبرات الكيات علمية الكيات وعملية

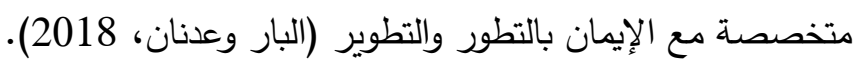

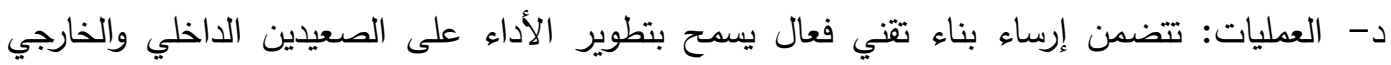

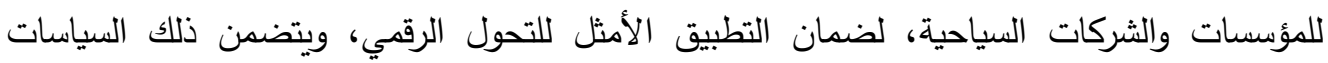

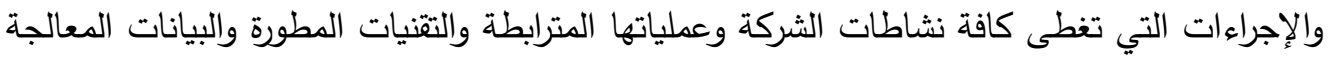

\section{(دبوسي وربيع، 2015). \\ 4 - التحول الرقمي في قطاع السياحة} يعد قطاع السياحة أحد القطاعات الاقتصادية الأكثر قدرة على دفع عجلة التتمية الاقتصادية والاجتماعية

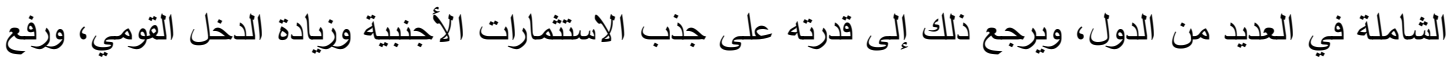

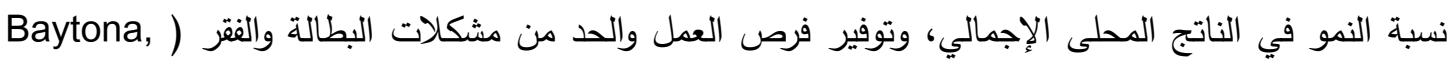
.(2019

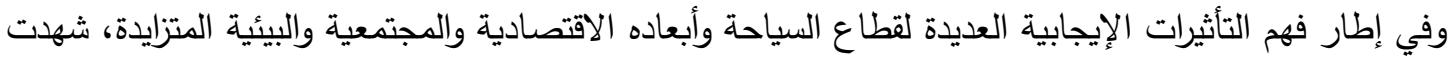
السنوات الأخيرة اتجاها واضحا لتطوير قطاع السياحة من خلال الاهتمام بتوفير الابتكار والتجديد، وإدخال

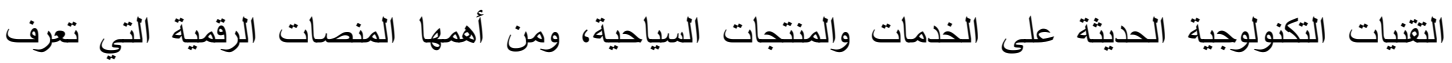

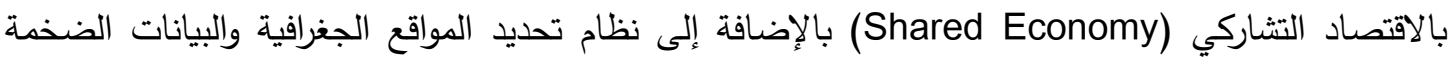
وتتنيات الذكاء الاصطناعي وغيرها (عبد العزيز وبسمة، 2018).

فاعتماد تكنولوجيا التحول الرقمي في قطاع السياحة أو ما يعرف "بالسياحة الرقمية" جعل الترويج السياحي أكثر سرعة وسهولة وفاعلية، فازداد نمو المؤسسات السياحية التي تركز على تبنى هذه التكنولوجيا والثبكات الذكية

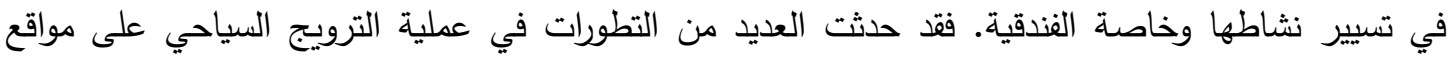

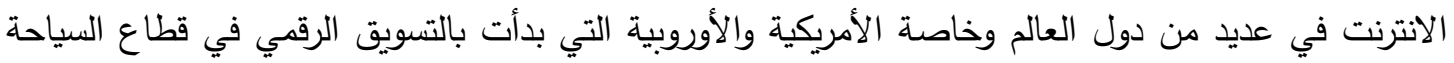

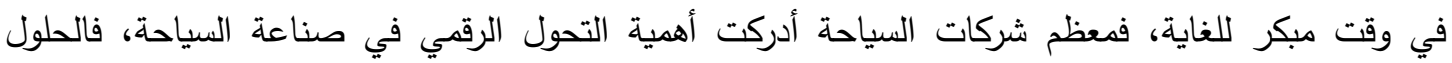

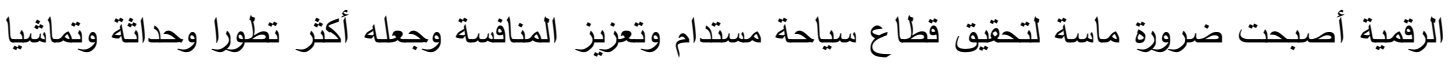




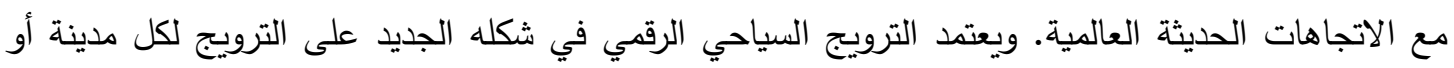
منطقة جذب سياحي على حدة، لتسليط الضوء على التتوع الذي يحتاجه السائح وتعريفه بالمناطق السياحية المختلفة لإبراز مميزاتها التتافسية وخصائصها، والعمل على تتمية المجتمعات المحلية المحيطة بهذه الأماكن السياحية (حسنية، 2021).

\section{5- الفوائد التي يحققها التحول الرقمي في قطاع السياحة}

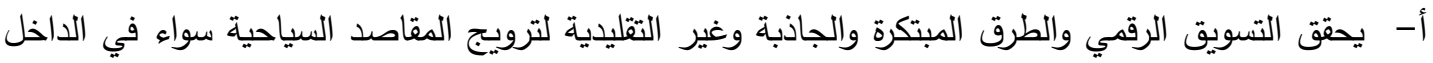

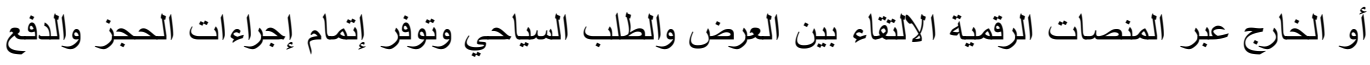
الإلكتروني للفنادق، والطيران والمنثآت والمزارات السياحية (بظاظو، ابراهيم، 2018). ب- تحقيق التنمية السياحية المستدامة من خلال دعم الاستثمارات السياحية التي تعتمد على استخدام التقنيات

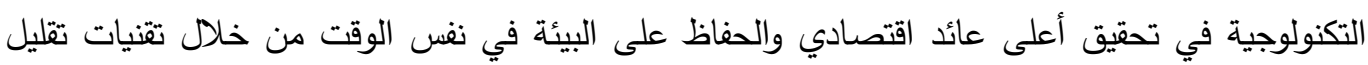

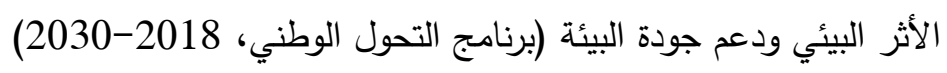
ج- تحديد المواقع الجغرافية التي تعتمد على البيانات الضخمة وتوفير كافة المعلومات للسائح عن المقاصد

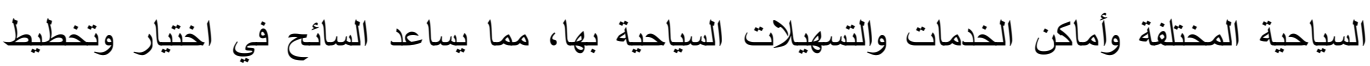
إجازته بنفسه (بظاظو وإبراهيم، 2018).

د- تطوير صناعة المتاحف الرقمية لزيادة فرص العرض وتتويع المنتج السياحي وزيادة المزايا النسبية

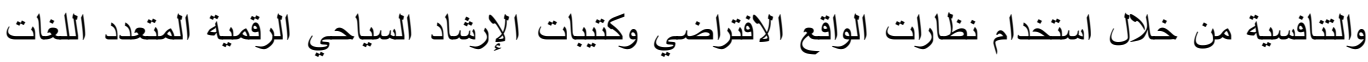

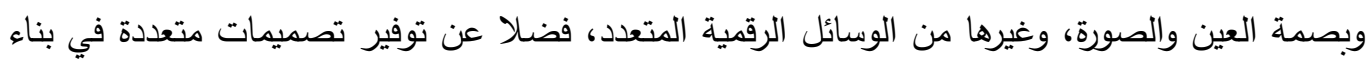
المنشآت الفندقية المعتمدة على تتنية الذكاء الاصطناعي لمعرفة احتياجات ومتطلبات السائحين وتلبيتها بالصور المثلى (بظاظو وإبراهيم، 2018). هـ - إدارة المواقع الأثرية والتراثية بصورة شمولية رقمية متكاملة تسهم في زيادة التنمية والتطوير المستدام لهذه

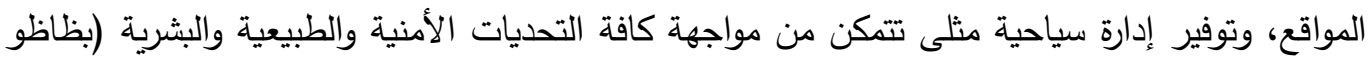

$$
\text { وآخرون، 2016).2016). }
$$

6- بعض الوسائل المستخدمة في التحول الرقمي في قطاع السياحة أوضحت حسنية (2012) أن هناك بعض الوسائل المهمة التي تستخدم في التحول الرقمي في قطاع الكيأل السياحة يمكن حصرها فيما يلي: أ- شبكة الإنترنت: بعد انتشار شبكة الإنترنت وتزايد عدد مستخدميها حول العالم، تحولت التظظيمات السياحية المختلفة نحو هذا الوسيط الجديد الذي يعتبر أكثر سرعة وسهولة ودقة وتتوعا في إيصال الخدان الخدمة

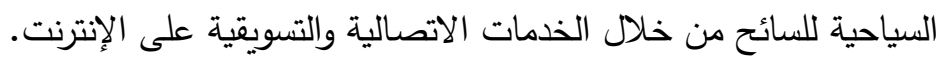


ب- المواقع الإكترونية: لقد عوضت خدمات مواقع الويب الكثير من المهام التي تتطلب زيارة مكاتب السياحة

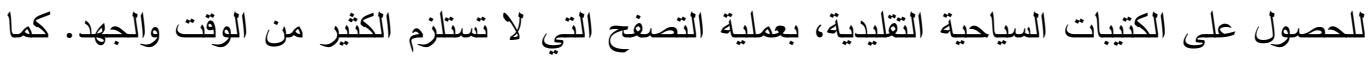
يستطيع الويب أن يمنحنا معلومات عن الطقس والمسكن والمعلومات التاريخية ومراكز الترفيه ووسائل النقل والخرائط وشركات الطيران ومواعيد الرحلات والفنادق وتأجير السيارات .... الخ. ت- البريد الإكتروني: وهو من أهم خدمات الإنترنت التواصلية حيث يقوم بنقل الرسائل بسهولة وسرعة وبدون

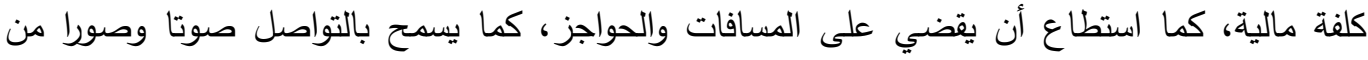

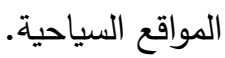

ث- الددونات: وهي الدداخلات التي تمكن السائح من تسجيل آرائه في جودة الخدمة الدقدمة إليه والتي تكون بمثابة رقيب على الخدمات المقدمة إليه.

ج- تقنية النشر المتزامن البسيط: وهي وسيلة سهلة تمكن القارئ من الحصول على ما يستجد من اخبار ومواضيع فور ورودها على موقعه المفضل على شبكة الإنترنت، مما يجعل هذه الخدمة وسيلة تساعد شركات السياحة على نثر جديدها وتسهل على السائح معرفة كل ما يستجد في عالم السياحة. ح- الثبكات الاجتماعية: وهي استخدام تطبيقات الإنترنت للتواصل والاتصال بالغير التي تتيح لمستخدميها

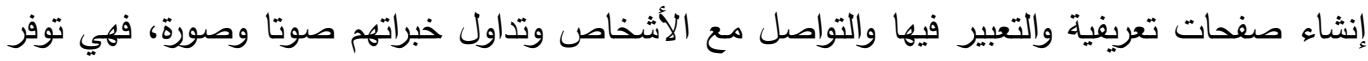
اللسائح فرصة التعرف أكثر على المناطق والخدمات السياحية عبر الصفحات التي تمتلكها شركات السياحة والطيران والفنادق والقرى السياحية.

خ- برامج خدمات الهاتف النقال: فبرمجيات الهاتف المحمول الذكي أصبحت أهم مصادر المعلومات حول

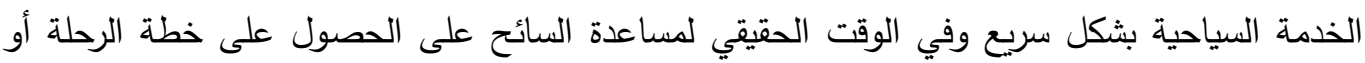
مكان توافر خدمة معينة او حجز موعد رحلة ... وغيرها من القرارات السياحية.

\section{7- صعوبات التحول إلى السياحة الرقمية}

تتمتع مصر بمقومات سياحية مهمة تجعلها قطبا سياحيا متميزا يوفر للسائح أنواعا سياحية متعددة، إلا أن التحول نحو نمط السياحة الذكية في ظل عملية التحول الرقمي، جعلها تواجه عدة مصاعب مرتبطة بطبيعة تكنولوجيا الاتصالات الجديدة والمتسارعة التطور والمرتفعة التكاليف، بالإضافة إلى مشكلات اخرى أهمها ما لأليا

أ- طبيعة القرى والمدن السياحية: تعتبر المدن والقرى السياحية بعيدة عن ظاهرة الذكاء في مختلف أبعادها،

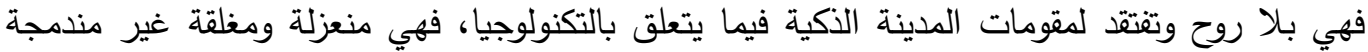
وغير متكاملة. فقد بنيت هذه المدن والقرى بنية استيعاب الجموع الهائلة من طلبات السكن لتكون مراقد وليس فضاءات حيوية متكاملة ومندمجة للتعاون والتضامن والابداع بغاية النشاط والاستدامة (المنصوري، 
ب- ضعف محتوى التطبيقات السياحية الذكية: ظهرت العديد من التطبيقات السياحية الذكية على منصة "Google play" أغلب هذه التطبيقات تستعمل لغة واحدة (سميرة وعبد المجيد ،2019). البنية التحتية والهيكل التنظيمي: تحتاج تتمية الاعمال السياحية في ظل التحول الرقمي إلى احداث تغيرات جوهرية في البنية التحتية والتتظيمية للمؤسسات السياحية، فيجب اعادة تتظيم هيكل المؤسسة ودمج بعض الانشطة واعادة النظر في طرق التسويق الإككترني المتبعة بما يتماشى مع التطورات التكنولوجية المتجددة (حسنية، 2021). ج- ارتفاع تكلفة تصميم وانشاء المواقع الاكترونية السياحية: ان تصميم وتطوير ومتابعة مثل هذه المواقع يحتاج إلى توافر خبراء متخصصين في هذا المجال وعلى درجة عالية من الكفاءة مما يجعلها مرتفعة التكلفة، بحيث تكون مواقع قادرة على جذب انتباه العملاء من السائحين مما يحقق ميزة تتافسية للمنتج المعلن عنة في الموقع (فتحي ، 2011).

د- التطورات السريعة في أعداد وطبيعة المواقع الالكترونية: هناك تزايد مستمر في أعداد وطبيعة المواقع الالكترونية على شبكة الانترنت واقبلا واسعا، مما يزيد من حدة التنافس بين هذه المواقع (صبري،

هـ - اللغة المصمم بها الموقع الاكتروني السياحي: تمثل لغة الموقع عاملا مهما في جذب العملاء من السائحين حتى يمكن من إحداث تفاعل بين الموقع وزواره مما يحتم تواجد نظام ترجمة لأهم اللغات العالمية لتيسير الاستفادة منها.

و - الخصوصية وأمن المواقع: قد تحتاج عملية التعامل مع المواقع الإلكترونية إلى الحصول على بعض ذالى البيانات ذات الخصوصية من العملاء، مما قد يؤثر على تقبل بعض العملاء لفكرة التسوق الإكتروني عبر الانترنت لذا وجب على المواقع الاكترونية استخدام البرمجيات الخاصة بالمحافظة على خصوصية

$$
\text { وسرية بيانات العملاء (فتحي، 2011). }
$$

ز - استخدام أسلوب الدفع الإكتروني: يمثل عنصر الثقة في أسلوب الدفع الإلكتروني أحد المعوقات الهامة

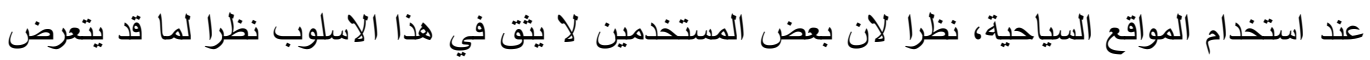
له هذا الاسلوب من اختراقات للنظام الإكتروني الخاص به، مما جعل هذ الشكل من الدفع تحديا كبيرا امام تطور السياحة الذكية، الامر الذي يتوجب علية تكثيف الجهود لتطوير امن انظمة الافع الالكتروني

$$
\text { (ذهبية والبشير ، 2015). }
$$

8- أثر التحول الرقمي على مستقبل السياحة في مصر يعتبر التحول الرقمي خطوة مهمة وفعالة لتنشيط القطاع السياحي المصري، حيث يساهم في الترويج للأماكن الأثرية وإظهار قيمة المعالم التاريخية المصرية، من خلال ترويجها عبر شبكات ومواقع التواصل الاجتماعي والصفحات الخاصة بوزارة السياحة والآثار ، وقد شهد قطاع السياحة عمليات تطوير كثيرة، وتم استحداث وحدات 
لجمع البيانات وإعداد قوائم بيانات للعاملين بقطاع السياحة، وتوقيع بروتوكول تعاون مع وزارة الاتصالات وتكنولوجيا المعلومات لتطوير البنية التكنولوجية، مما يؤكد على توجه السياحة نحو التحول الرقمي وتسهيل

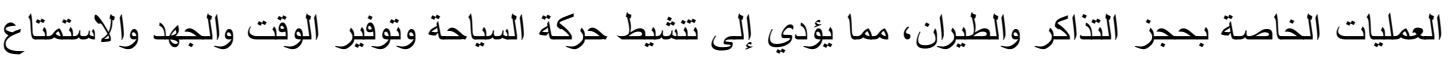

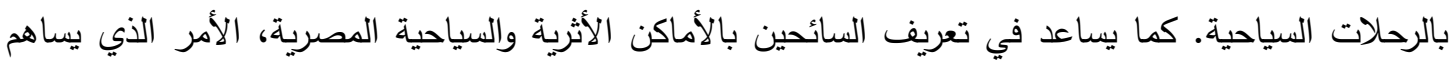

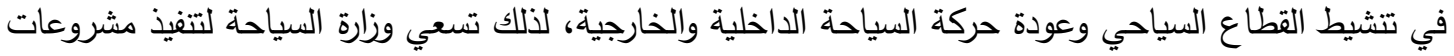
التحول الرقمي سواء في حجوزات الطيران أو التأثيرات أو المطاعم والفنادق. مما لا شك فيه أنداء أن تطبيق التقنيات

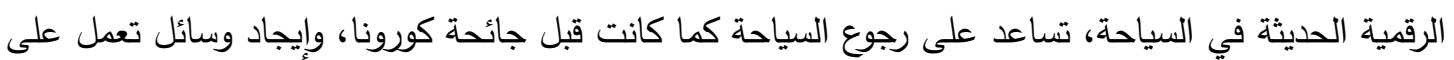

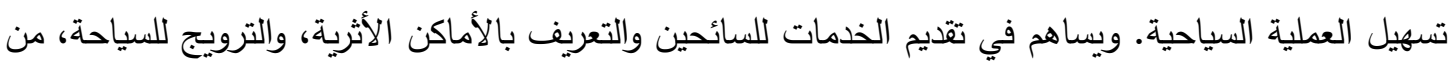
خلال تسهيل كافة الاجراءات للسائحين، وتحديد الرحلات والبرامج السياحية. وتسهيل العمليات الخاصة بحجز التذاكر والطيران، وبالتالي تتشيط القطاع السياحي وبناء منظومة معلوماتية وتكنولوجية حديثة (سالي، 2021).

ثانيا: الدراسات السابقة دراسة طارق وآخرون (2016)، بعنوان "تطبيقات السياحة الرقمية ودورها في تعزيز رقمنة المجتمعات والتحول نحو المدن السياحية الذكيـة". أجري البحث بهدف تسليط الضوء على أهمية رقمنة خدمات النقل والاتصالات

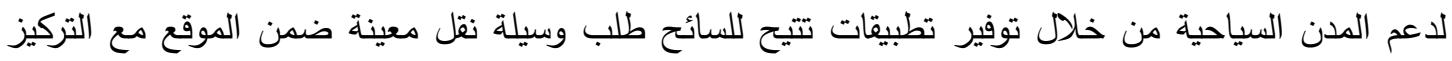
على تمكين النظام لخدمات تحديد المواقع ليتسنى للسائح تحديد موقع أقرب وسيلة نقل والحصول عليها دون تأخير • واظهرت النتائج، عن اهمية تخطيط منظومات نقل واتصالات رقمية لتأثيرها الكبير في التتمية السياحة

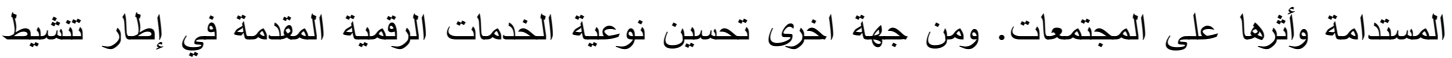

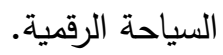

دراسة (2018) Alsarayreh and SaltK، هدفت هذه الدراسة إلى التعرف على مدى توافر الوسائل

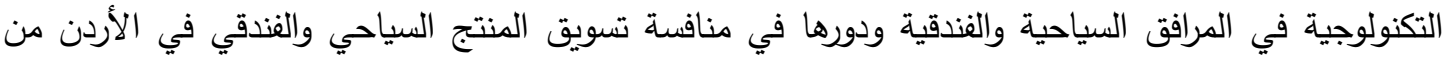

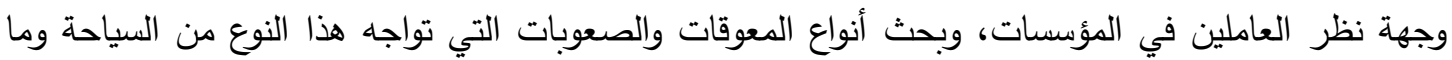

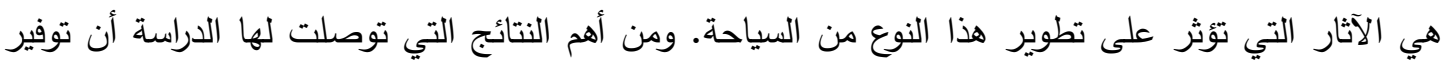

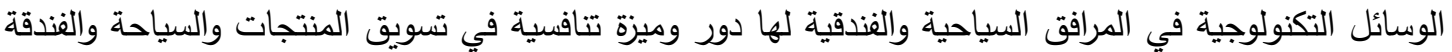
في الأردن من وجهة نظر العاملين فيها.

هدفت دراسة محمد والأشقر (2018) إلى التعرف على أثر وسائل التسويق الإلكتروني في بناء الميزة التتافسية لثركات الطيران، كما هدفت إلى التعرف على أثر استخدام المواقع الإلكترونية للتواصل مع العملاء في بناء

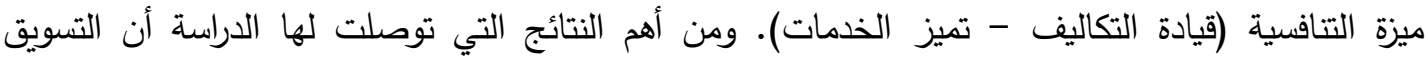

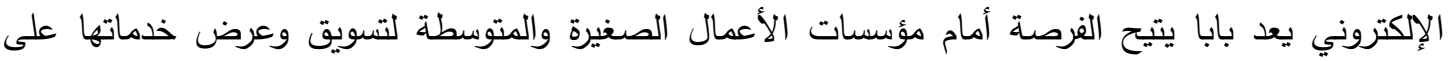

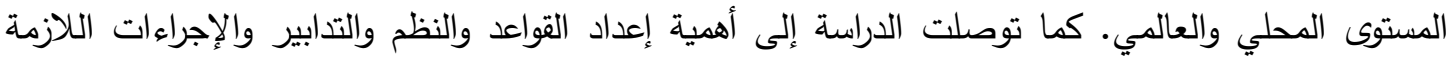
للتجارة الإكترونية والمساندة المباشرة والغير مباشرة للشركات للتحول إلى النظم الإككترونية. 
حددت دراسة عبادي وزهواني (2019) تجليات التحول الرقمي ودوره في تفعيل السياحة الداخلية، حيث هدف البحث إلى إبراز أهية إدخال تقنيات الرقمنة ومعلومات الاتصال لتتشيط قطاع السياحة في الجزائر ـ واوضحت

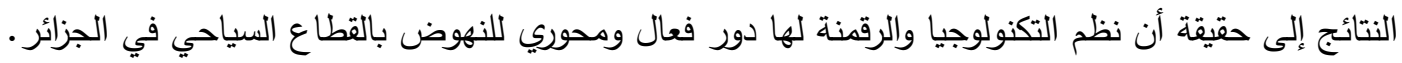
دراسة غادة (2019) بعنوان "التحول الرقمي في السياحة المصرية (المفهوم، التحديات، المتطلبات)" هدفت الدراسة إلى تتنيط وتحسين جودة وخدمات السياحة الدولية من خلال مواكبة التقنيات التكنولوجية الحديثة في

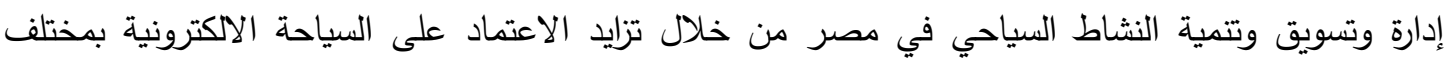

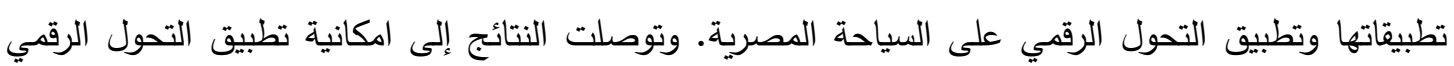

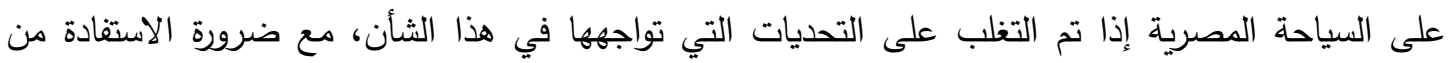
التجارب الناجحة في هذا الججال ومحاولة تطبيقها، مع تتفيذ آليات فعلية لتطبيق التحول الرقمي على السياحة

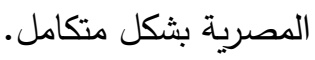

دراسة سلامى ولبوشي (2019) بعنوان "التحول الرقمي بين الضرورة والمخاطر". وقد أظهرت نتائج الدراسة ان

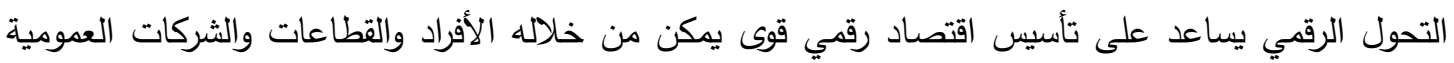

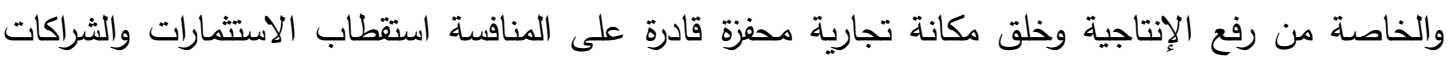

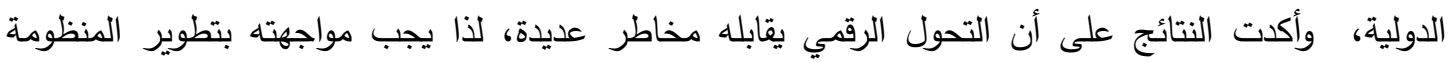

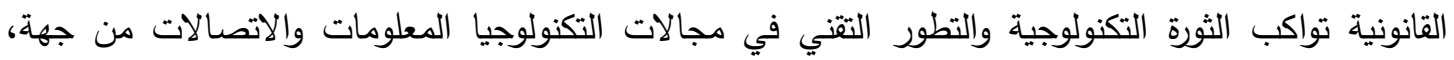

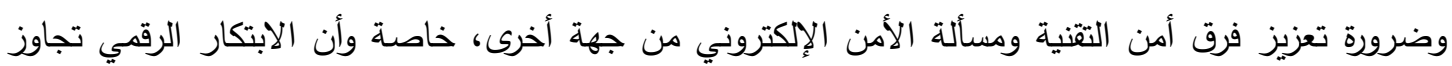
تدابير الأمن الإكتروني الذي يعتبر من أبرز تحديات التحول الرقمي.

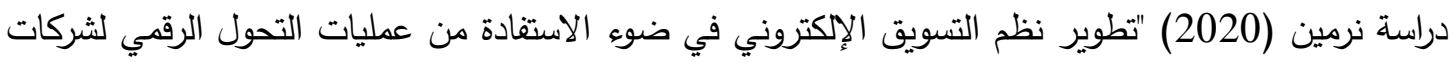
السياحة والسفر". هدفت الدراسة إلى التعرف على متطلبات التحول الرقمي الداعمة لنظم التسويق الإلكتروني،

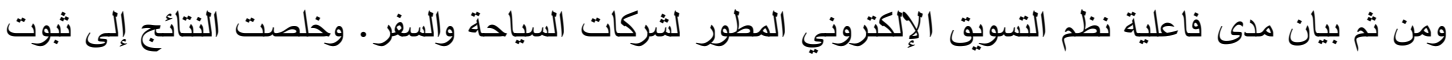

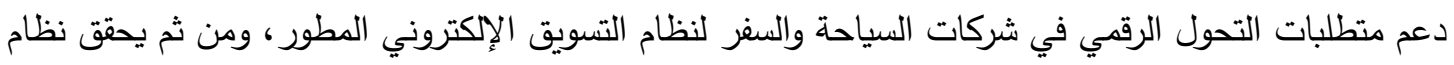

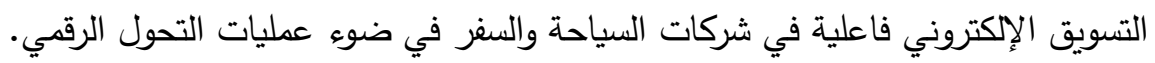
دراسة محمد (2021) بعنوان "دور التسويق السياحي الإلكتروني وأثره على تتمية القطاع السياحي الأردني".

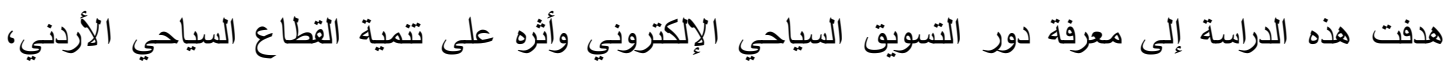
والتعرف على واقع تتشيط وتتمية القطاع السياحي في الأردن المتبع في وازرة السياحة الأردنية ومن أهم النتائج

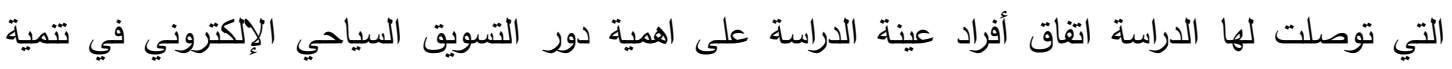

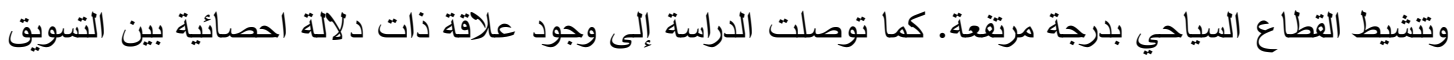
السياحي الإلكتروني وتتمية القطاع السياحي الأردني.

دراسة حسنية (2021) بعنوان "صعوبات التحول إلى السياحة الذكية في الجزائر - مقاربة نظرية تحليلية" اوضحت الدراسة ان عالمية الطلب السياحي تجعل من المنافسة أكثر حدة، وهو ما دفع السياحة لتكون اولى لى لئل 
القطاعات التي تستخدم الانترنت لترويج خدماتها في ظل تطور المدن الذكية التي تعتمد كل خدماتها على التى

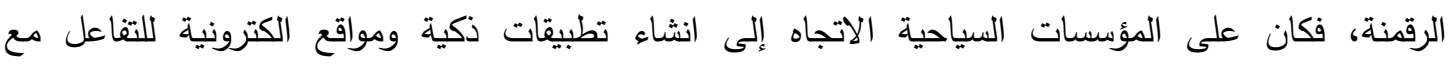

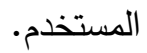

دراسة Afaneh (2021) هدفت هذه الدراسة إلى تحليل ظاهرة السياحة الإكترونية ودراسة تأثير السياحة

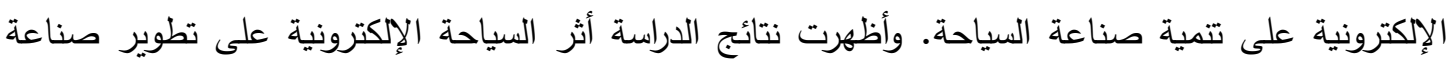

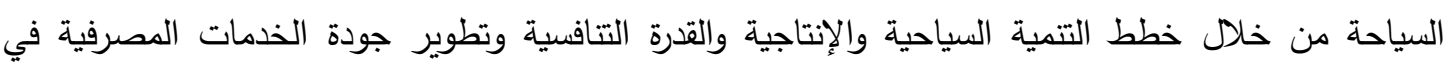

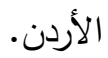
وتهدف هذه الدراسة الى ايجاد إطار مقترح للعلاقة التأثيرية بين دور التحول الرقمي وتطوير المنتج السياحي بهدف زيادة القدرة التنافسية والقيمة المضافة للقطاع السياحي. 8- - 1 - الدراسة الميدانية مقدمة الدراسة الميدانية تهدف الدراسة الميدانية إلى إيضاح العلاقة التأثيرية بين دور التحول الرقمي وتطوير المنتج السياحي بهدف

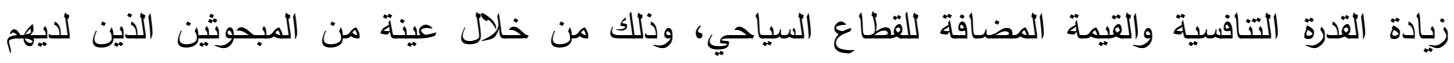

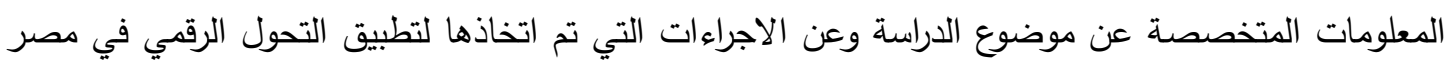

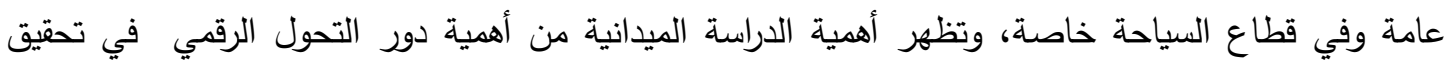

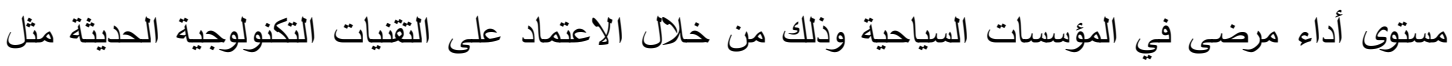

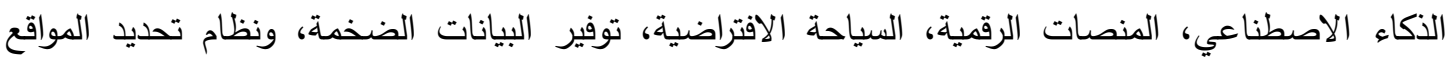

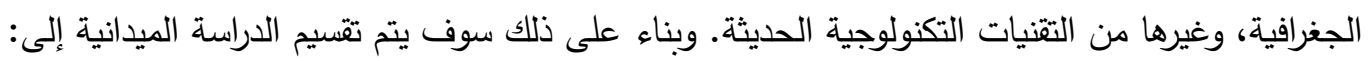

\section{أولا: مناقثة المنهجية والإجراءات الخاصة بالدراسة الميدانية} وصف أداة الدراسة الميدانية

تتمثل أداة جمع البيانات التي تم الاعتماد عليها في الحصول على التية البيانات الأولية اللازمة للدارسة الحالية في

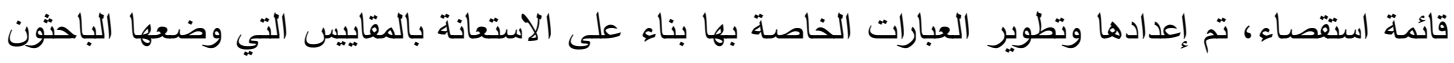

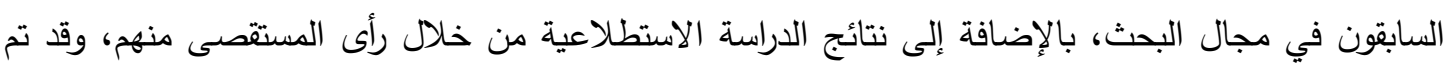

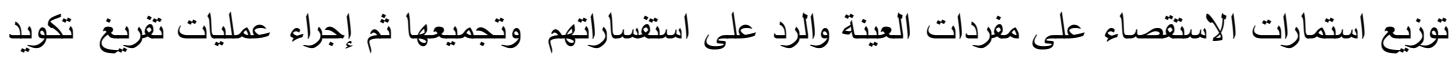

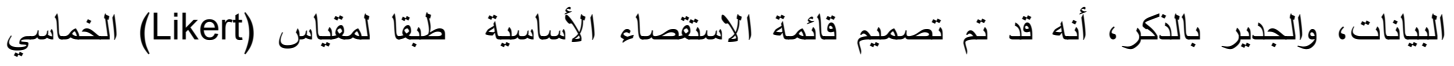

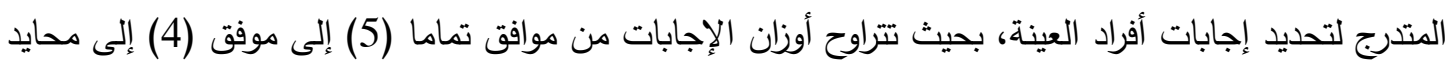

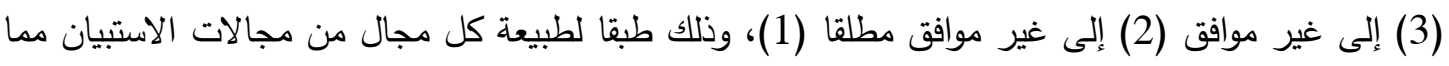
يمكن من الحصول على بيانات متصلة ولضمان إحداث توزيع طبيعي للبيانات حتى تتبل تطبيق الأساليب الإحصائية عليها.

واشتملت قائمة الأسئلة على الأجزاء التالية: 
الجزء الأول: تضمن مجموعة من الأسئلة الديموغرافية التي تحدد بعض الخصائص الهامة للمستقصى منهم للتأكد من مدى اهتمامهم بموضوع البحث. الجزء الثاني: انقسم إلى ثلاثة محاور على النحو التالي: المحور الأول: مدى توافر البنية الأساسية والاستراتيجيات الأساسية لتطبيق التحول الرقمي في قطاع السياحة المصرية: وقد اشتمل على 10 عبارات من (1-10).

المحور الثاني: توافر الخدمات الرقمية المستهدفة في المؤسسات السياحية: وقد اشتمل على 10 عبارات من .(20-11)

الثالث: الصعوبات التي تواجه تطبيق التحول الرقمي في قطاع السياحة المصرية: وقد اشتمل على 6 المحور عبارات من (21-26). 3- مجتمع وعينة الدراسة الميدانية أ- - مجتمع الدراسة

تحقيقًا لأهداف الدراسة يتكون مجتمع الدراسة من كافة المعنيين والمخططين للنشاط السياحي والسفر في الأجهزة

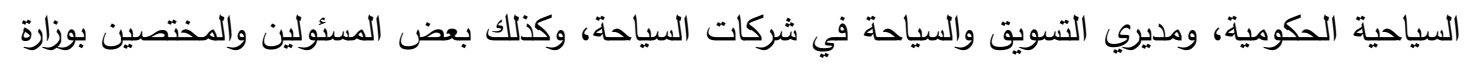

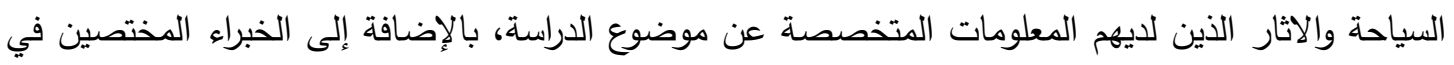
مجال تكنولوجيا المعلومات والاتصالات.

ب - بينة الاراسة نظرا لتعذر استخدام أسلوب الحصر الثامل في جمع البيانات الخاصة بالدراسة الحالية لعدة اعتبارات منها

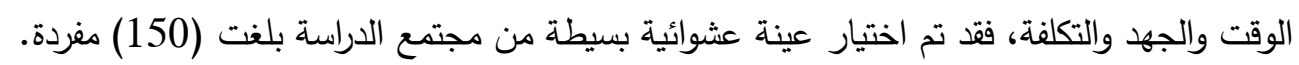
تم استخدام أسلوب التخصيص Proportion Allocation وذلك حتى يتم توزيع عينة الدراسة على الفئات

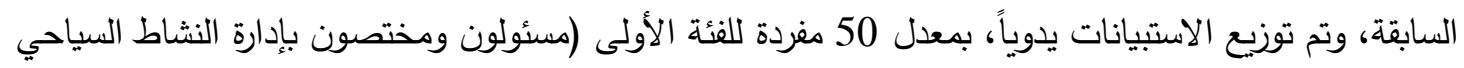

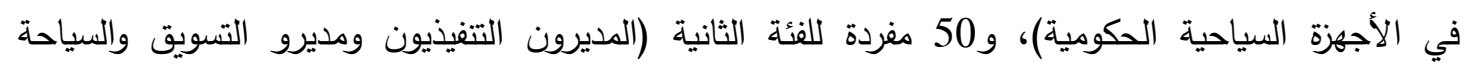

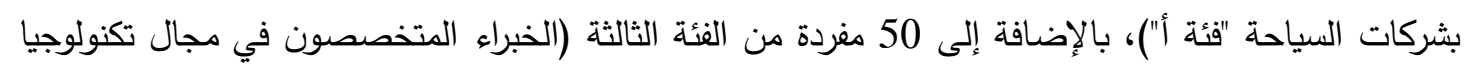

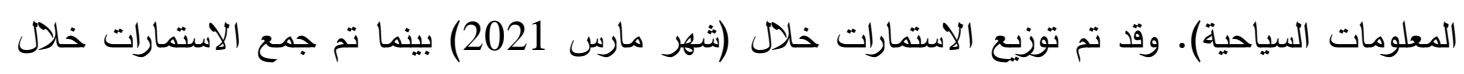
شهر ابريل 2021.

وقد تم جمع (138) استمارة استبيان بنسبة (92\%) وبعد إجراء التحليلات الإحصائية الخاصة بالقيم المفقودة

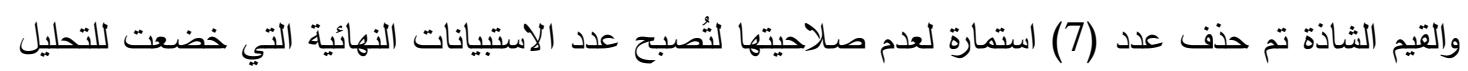
الإحصائي (131) استمارة بنسبة (87.33\%) من إجمالي عدد الاستمارات الموزعة. 
ويوضح جدول (1) عينة الدراسة موزعة طبقا لفئات المستقصي منهم لكل فئة على حده وفقا للاستمارات الصحيحة التي وردت من عينة الدراسة.

جدول (1) عينة الدراسة موزعة طبقا لفئات المستقصي منهم لكل فئة على حده وفقا للاستمارات الصحيحة.

\begin{tabular}{|c|c|c|c|c|}
\hline لاللاستمارئية & الاستمارات & الاستمارات & الاستمارات & فئة المستقصي منهح \\
\hline$\% 32.82$ & 43 & 45 & 50 & الأجهزة الحكومية ومختصون بإدارة النشاط السياحي في \\
\hline$\% 32.06$ & 42 & 46 & 50 & بشركات السياحة "فئة أل" ومديرو التسويق والسياحة \\
\hline$\% 35.12$ & 46 & 47 & 50 & المعبراء المتخصصون في مجال تكنولوجيا \\
\hline 100 & 131 & 138 & 150 & الإجمالي \\
\hline
\end{tabular}

ويوضح جدول (2) الخصائص الديموغرافية لأفراد عينة الدراسة طبقا للمؤهل الدراسي وسنوات الخبرة بالإضافة

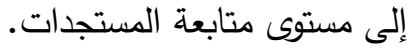

جدول (2) تقسيم عينة الدراسة حسب الخصائص الديموغرافية للمستقصى منهم.

\begin{tabular}{|c|c|c|c|}
\hline النسبة المئوية & العدد العد & الفئة & الخاصية \\
\hline 51.15 & 67 & بكالوريوس & \multirow{4}{*}{ 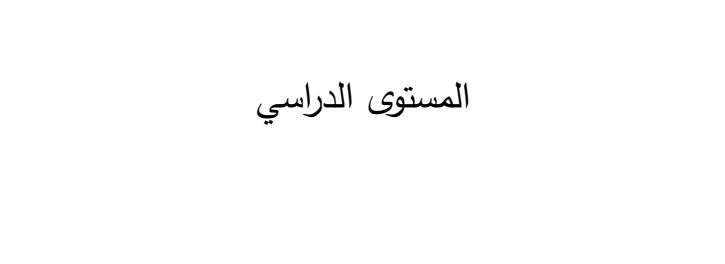 } \\
\hline 26.72 & 35 & دبلوم دراسات عليا & \\
\hline 16.03 & 21 & ماجستير & \\
\hline 6.11 & 8 & دكتوراه & \\
\hline 24.43 & 32 & أقل من 5 سنوات & \multirow{3}{*}{ 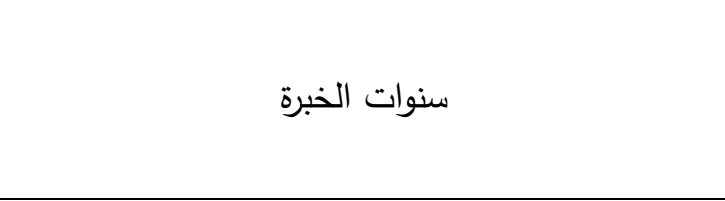 } \\
\hline 42.75 & 56 & من 5-10 - 5 - 5 & \\
\hline 32.82 & 43 & أكثر من 10 & \\
\hline 82.44 & 108 & متابع & \multirow[t]{2}{*}{ متابعة المستجدات التي يتم إضافتها بعلم التحول الرقمي } \\
\hline 17.56 & 23 & 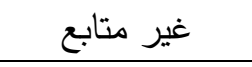 & \\
\hline 100 & 131 & \multicolumn{2}{|r|}{ الإجمالي } \\
\hline
\end{tabular}

يتضح من الجدول السابق أن نسبة عينة البحث كبيرة ومتخصصة في مجال الدراسة يمكن الاعتماد على النتائج المتحصل عليها منها.

4- الصدق و الثبات بطريقة ألفا كرونباخ

تم تقدير الصدق والثبات من خلال مقياس (ألفا) Gronbatch Alpha فإذا زاد هذا المقياس عن 0.60 أمكنات 0.6 أمكن

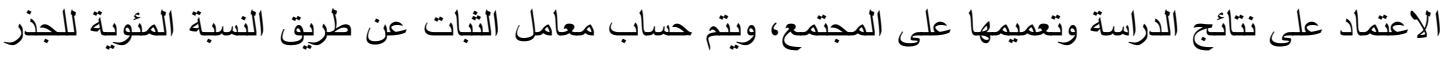


التربيعي لمعامل الصدق (قيمة ألفا). ويوضح جدول (3) أن قيمة كل من معاملي الصدق والثبات لمحاور

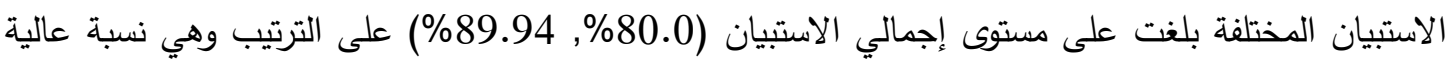
مما يؤكد أمكانية الاعتماد على نتائج التحليلات الإحصائية وإمكانية تطبيقها على مجتمع الإنى الداسة. جدول (3) مقاييس الصدق والثبات لمحاور الاستبيان المختلة وفقا لاختبار ألفا كرونباخ.

\begin{tabular}{|c|c|c|c|}
\hline الثبات & (قيمة ألفا) & 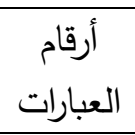 & محاور الاستبيان \\
\hline 87.30 & 0.762 & $10-1$ & 1. مدى توافر البنية الأساسية والاستراتيجيات الأساسية لتطبيق التحول \\
\hline 83.60 & 0.699 & $20-11$ & 2. توافر الخدمات الرقمية المستهدفة في المؤسسات السياحية \\
\hline 81.06 & 0.657 & $21-26$ & 3. الصعوبات التي تواجه تطبيق التحول الرقمي في قطاع السياحة \\
\hline 89.4 & 0.800 & $26-1$ & 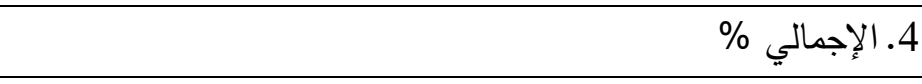 \\
\hline
\end{tabular}

5- اختبار التوزيع الطبيعي لبيانات الاستبيان.

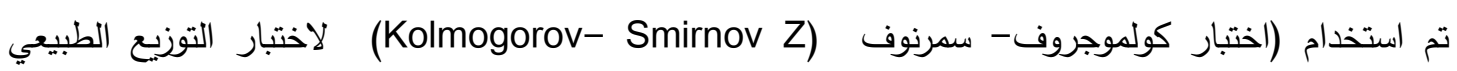

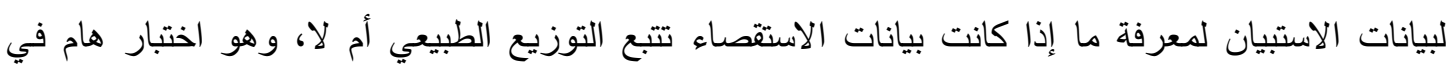

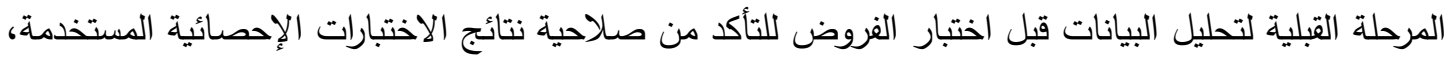

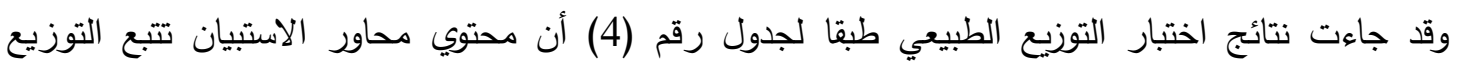

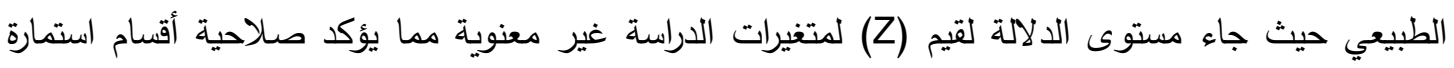
الاستبيان لإجراء التحليل الإحصائي عليها. جدول (4) نتائج اختبار (Kolmogorov- Smirnov Z) للتوزيع الطبيعي لبيانات محاور الاستبيان المختلفة.

\begin{tabular}{|c|c|c|}
\hline المعنوية & 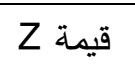 & محاور الاستبيان \\
\hline 0.168 & 1.570 & 5. مدى توافر البنية الأساسية والاستراتيجيات الأساسية لتطبيق التحول \\
\hline 0.186 & 1.090 & 6. توافر الخدمات الرقمية المستهدفة في المؤسسات السياحية \\
\hline 0.182 & 0.962 & 7. الصعوبات التي تواجه تطبيق التحول الرقمي في السياحة الدصرية \\
\hline
\end{tabular}

وبذلك تم التأكد من صدق وثبات أداة الدراسة بالإضافة إلى صلاحية التوزيع الطبيعي لبيانات الاستبيان مما

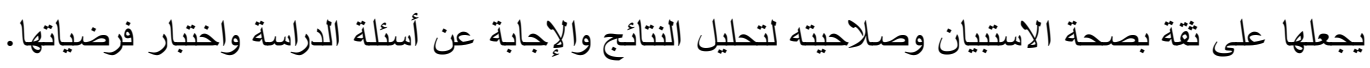

\section{6- متغيرات الدراسة}

يحتوي هذا البحث على نوعين من المتغيرات، هما: [أ] المتغيرات المستقلة: وتتمثل في الاتي: 
1. المتغيرات الخاصة بمدى توافر البنية الأساسية والاستراتيجيات الأساسية لتطبيق التحول الرقمي في قطاع السياحة المصرية. 2. المتغيرات الخاصة بتوافر الخدمات الرقمية المستهدفة في المؤسسات السياحية. 3. المتغيرات الخاصة بالصعوبات التي تواجه تطبيق التحول الرقمي في قطاع السياحة المصرية. [ب] المتغير التابع ويعبر عنة بتتغير تطوير المنتج السياحي ويتم تقدير قيمته من خلال متوسط قيم عبارات كل محور والتي تتميز

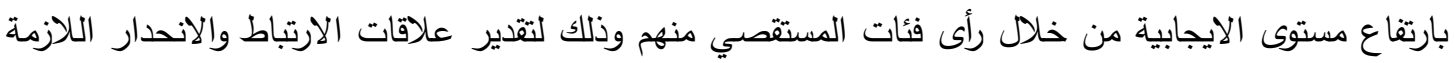
لتقدير إطار مقترح للعلاقة التأثيرية بين التحول الرقمي وتطوير المات المنتج السياحي بهدف تحسين الأداء المؤسسي في قطاع السياحة.

\section{7- الأساليب الإحصائية المستخدمة}

تم استخدام الأساليب الإحصائية المناسبة لتحليل نتائج استمارات الاستبيان طبقا لما ذكره Cochran and Snedecor, 1980) 1- مقاييس الاعتمادية والصلاحية: لاختبار صلاحية نتائج أسئلة قائمة الاستقصاء ومدى ملاءمتها لأهداف البحث. 2- التحليل الوصفي للمتوسطات المعيارية والوزن النسبي لفقرات الاستبيان الدختلفة.

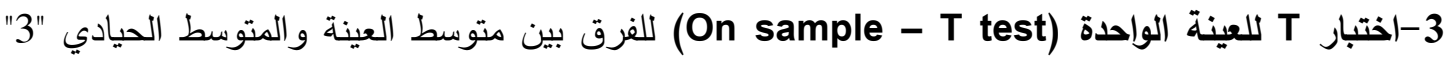
لفقرات الاستبيان المختلفة وتقدير الوزن النسبي لعبارات الاستقصاء بهدف قياس درجة الاستجابة الإيجابية أو السلبية لعبارات الاستقصاء لاى فئات المستقصى منهم كالأتي:

أ- تكون الفقرة إيجابية بمعنى أن أفراد العينة يو افقون على محتواها إذا كانت قيمة (t) المقدرة أكبر من قيمة

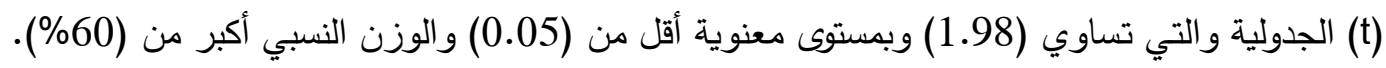
ب- تكون الفقرة سلبية بمعنى أن أفراد العينة لا يوافقون على محتواها إذا كانت قيمة (t) المقدرة أكبر من

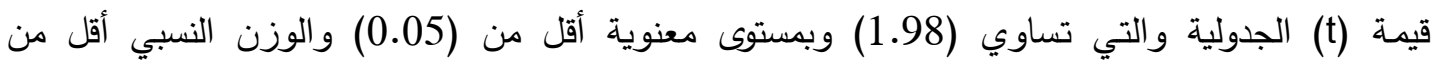

ج- تكون أراء العينة في الفقرة محايدة إذا كانت (غير معنوية) مستوى المعنوية لها أكبر من 0.05 والوزن النسبي لها يقرب من القيمة (60\%).

4- تحليل الارتباط (Correlation) وتقدير المساهمة النسبية (R2) بعناصر الاستبيان في أقسامه المختلفة

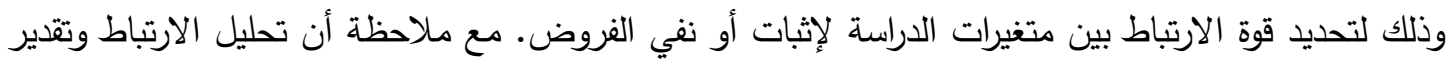


المساهمة النسبية يقوم باستبعاد أثر التحيز الثخصي في إجابات المستقصى منهم ومن هنا يمكن الاعتماد على الثى نتائج تقدير معامل الارتباط والمساهمة النسبية بدرجة ثقة مرتععة. 5- تحليل الانحدار المرحلي (Stepwise regression) بهدف للتوصل إلى إطار مقترح للعلاقة التأثيرية بين التحول الرقمي وتطوير المنتج السياحي بهدف زيادة القدرة التتافسية والقيمة المضافة للقطاع السياحي 8 - مروض الدراسة الميدانية

قسمت فروض الدراسة الميدانية طبقا لبنود استمارة الاستقصاء لدراسة العلاقات التأثيرية بين محاور الاستبيان

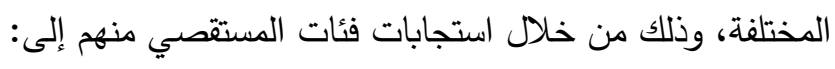
أ- الفرض الخاصة باختبار T للعينة الواحدة (On sample - T test) الفرض الأول: "لا توجد فروق بين آراء الفئات المستقصي منهم حول أهمية التحول الرقمي وتطوير المنتج

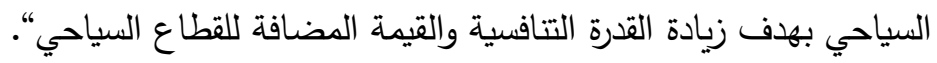
ب- الفروض الخاصة بتحليل الارتباط (Correlation). الفرض الثاني: "لا توجد علاقة ارتباط بين مدى توافر البنية الاساسية والاستراتيجيات الاساسية لتطبيق التحول الرقمي وتطوير المنتج السياحي". الفرض الثالث: "لا توجد علاقة ارتباط بين توافر الخدمات الرقمية المستهدفة في المؤسسات السياحية وتطوير

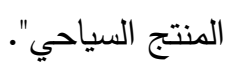
الفرض الرابع: "لا توجد علاقة ارتباط بين الصعوبات التي تواجه تطبيق التحول الرقمي في السياحة الدصرية وتطوير المنتج السياحي ".

ج- الفرض الخاص بتحليل الانحدار المرحلي (Stepwise regression)

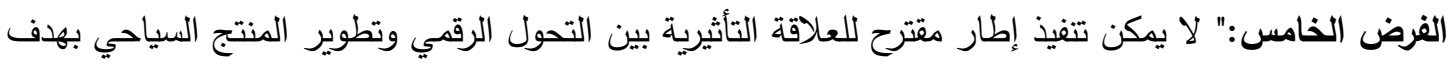
زيادة القدرة التتافسية والقيمة الدضافة للقطاع السياحي". ثانيا: تحليل النتائج ومناقثة الفرضيات فيما يلي أهم نتائج الدراسة الميدانية التي أجريت على البيانات الميات المتحصل عليا من نتائج الاستبيان. اختبار صحة الفرض النظري الأول "الا توجد فروق بين آراء الفئات المستقصي منهم حول أهمية التحول الرقمي وتطوير المنتج السياحي بهذف زيادة القدرة التنافسية والقيمة المضافة للقطاع السياحي“. يوضح جدول (5) نتائج اختبار t للعينة الواحدة حول محددات مدى توافر البنية الاساسية والاستراتيجيات

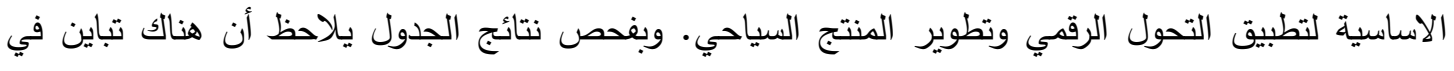
درجات الاستجابة لاى فئات المستقصي منهم حول عبارات الجدول كالآتي: 
- تميزت عبارات (2 و3 و4 و6 و7 و 8) بإيجابية عالية في محتواها في رأى فئات المستقصي منهم حيث

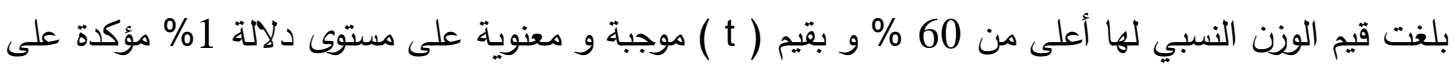

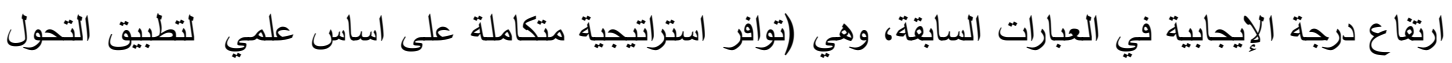

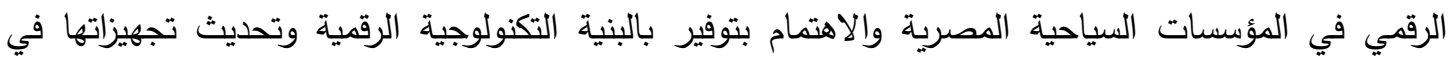

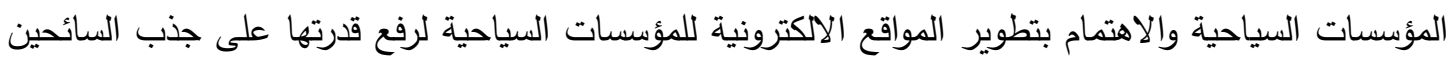

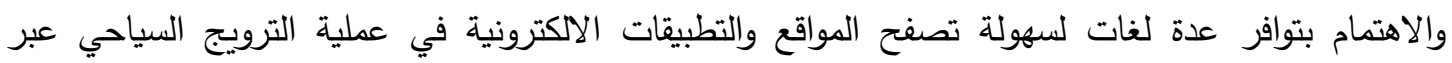
الانترنت والاهتمام بتدريب العاملين بالمؤسسات السياحية على استخدام عناصر وامكانيات التكنولوجيا الرقمية

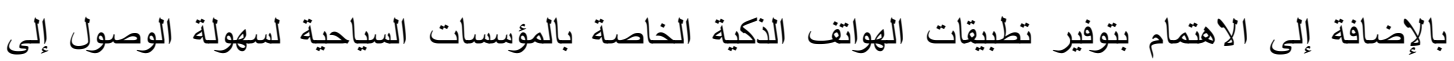

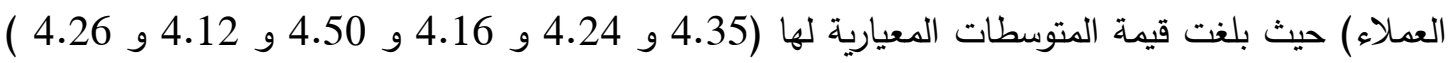

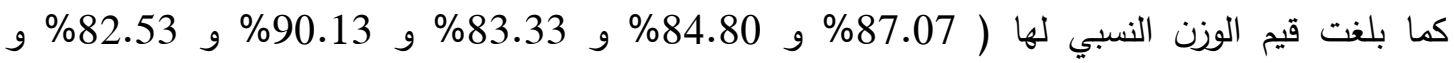
85.20\% على الترتيب وقد حصلت هذه العبارات على مساهمة نسبية مرتنعة، مما يؤكد على أهمية تأثيرها

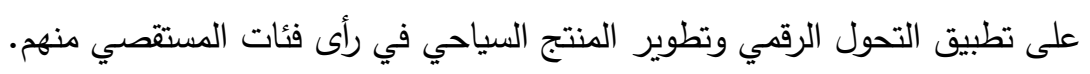
-أوضحت النتائج أيضا وجود استجابات منخفضة بين آراء فئات المستقصي منهم في الفقرات رقم (1 و5 و9 و و و 10 و

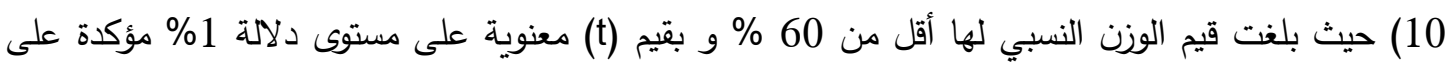

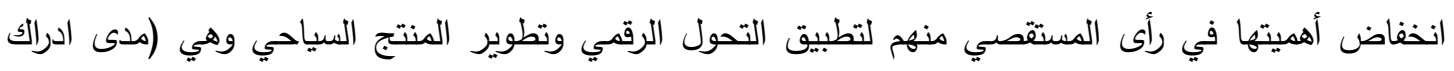

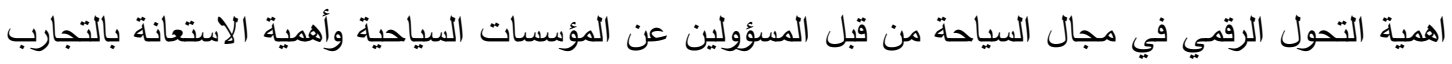

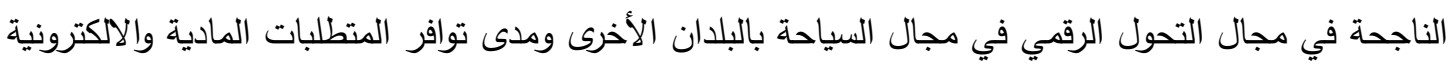

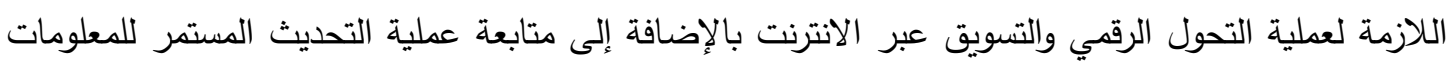

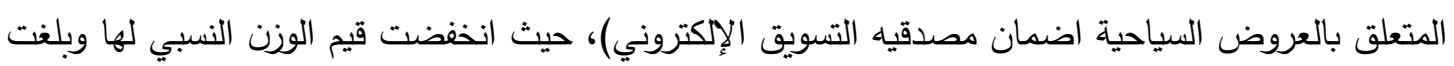
(52.35\% و 55.20\% و 52.93\% و 53.73\%) على الترتيب.

- - مأكدت النتائج أيضا عدم وجود فقرات ذات استجابة محايدة في محتواها في آراء فئات المستقصي منهم.

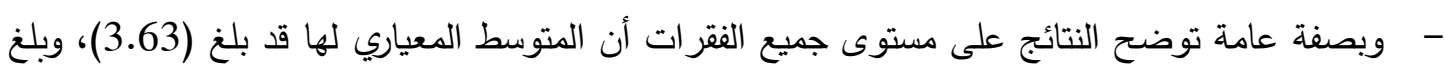

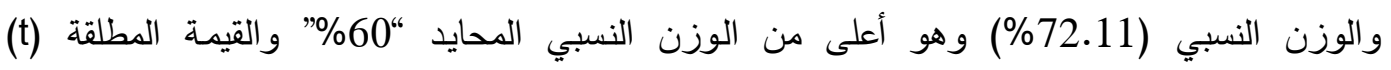

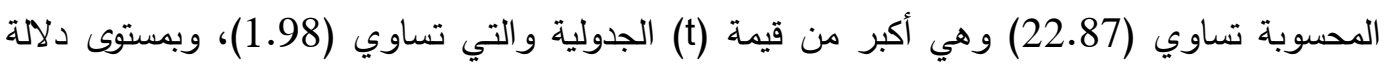

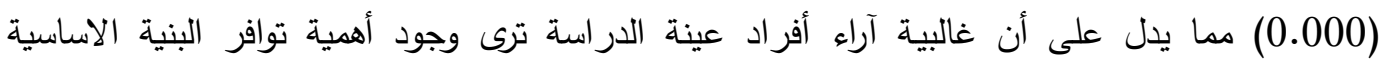

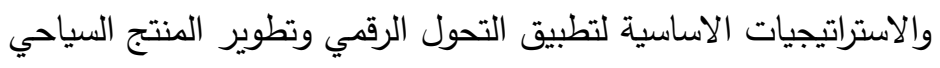


جدول (5) نتائج اختبار t للعينة الواحدة حول محددات مدى توافر البنية الاساسية والاستراتيجيات الاساسية

\begin{tabular}{|c|c|c|c|c|c|c|}
\hline الألهمية & المعنوية & قيمة & النسبي & الميار & المتوسط & الفقرة \\
\hline منخفضة & 0.000 & -5.24 & 52.35 & 0.072 & 2.61 & 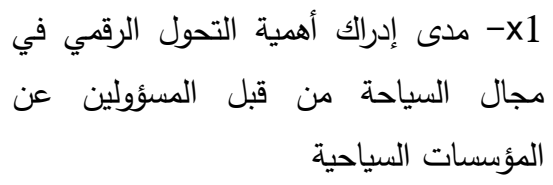 \\
\hline مرتفعة & 0.000 & 21.06 & 87.07 & 0.064 & 4.35 & 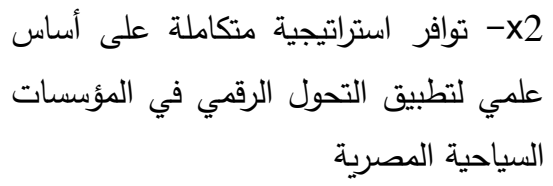 \\
\hline 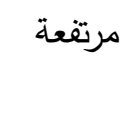 & 0.000 & 20.80 & 84.80 & 0.059 & 4.24 & 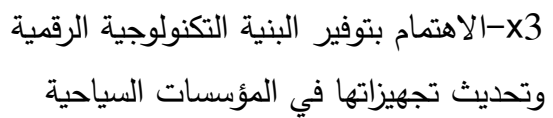 \\
\hline 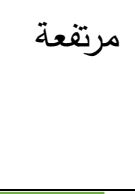 & 0.000 & 12.24 & 83.33 & 0.095 & 4.16 & 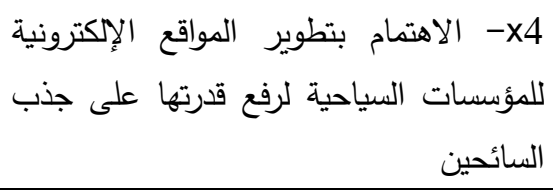 \\
\hline مـ يتبع & 0.000 & -3.60 & 55.20 & 0.066 & 2.76 & 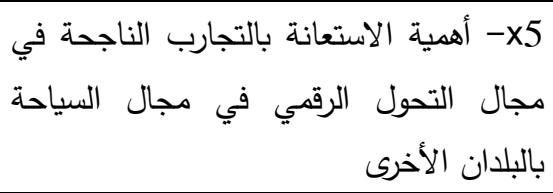 \\
\hline مرتفعة & 0.000 & 25.26 & 90.13 & 0.059 & 4.50 & 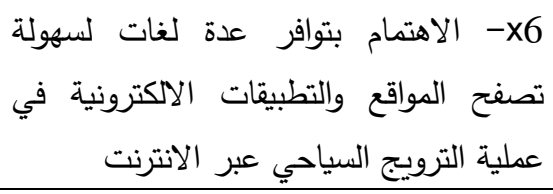 \\
\hline 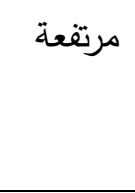 & 0.000 & 14.41 & 82.53 & 0.078 & 4.12 & 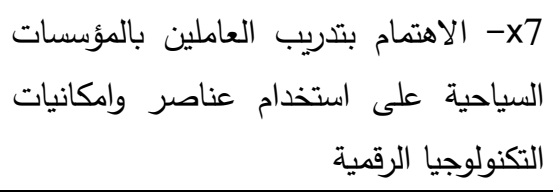 \\
\hline 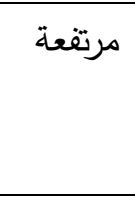 & 0.000 & 17.89 & 85.20 & 0.070 & 4.26 & 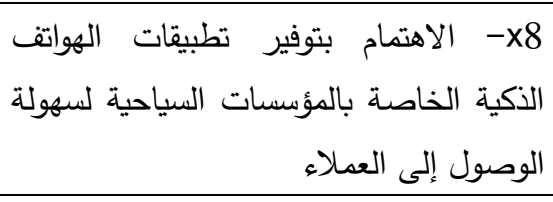 \\
\hline منخفضة & 0.000 & -5.12 & 52.93 & 0.068 & 2.64 & 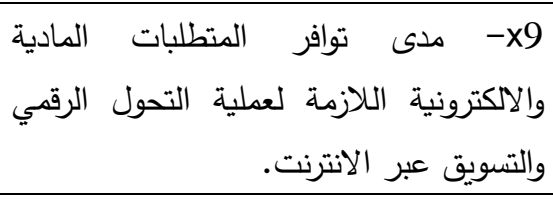 \\
\hline منخفضة & 0.000 & -4.34 & 53.73 & 0.072 & 2.68 & 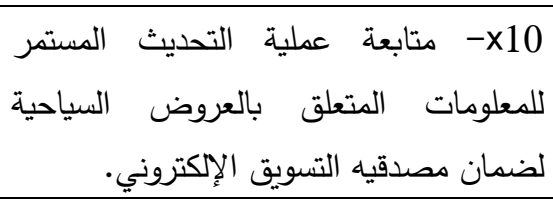 \\
\hline & 0.000 & 22.87 & 72.71 & 0.027 & 3.63 & 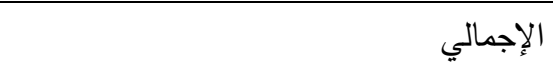 \\
\hline
\end{tabular}


يوضح جدول (6) نتائج اختبار t للعينة الواحدة حول محددات توافر الخدمات الرقمية المستهدفة في المؤسسات

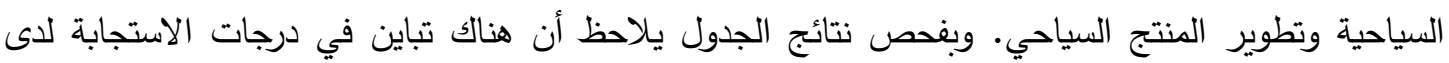
فئات المستقصي منهم حول عبارات الجدول كالآتي: - تميزت عبارات (12 و14 و15 و17 و18 و19) بإيجابية عالية في محتواها في رأى فئات المستقصي منهم

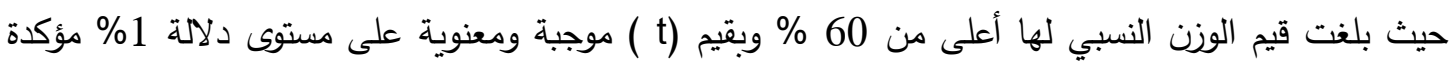

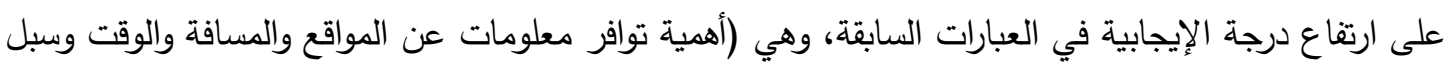

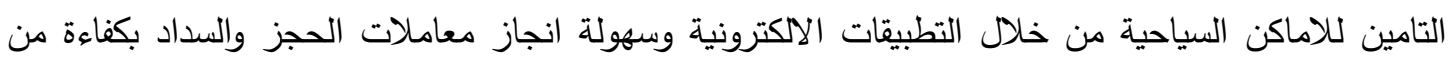

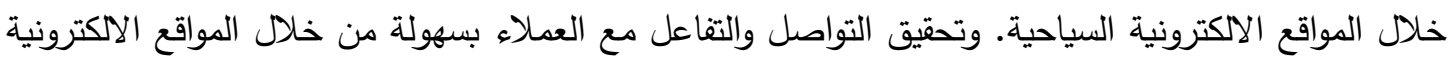

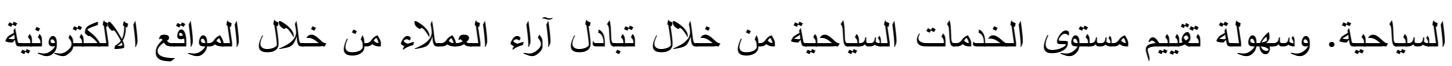
السياحية وسهولة وسرعة اجراء عمليات المقارنة بين العروض السياحية من خلال الخدمات الرقمية مما يساعد الريات

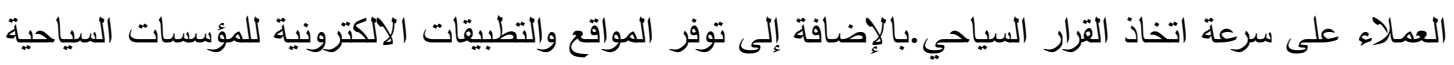

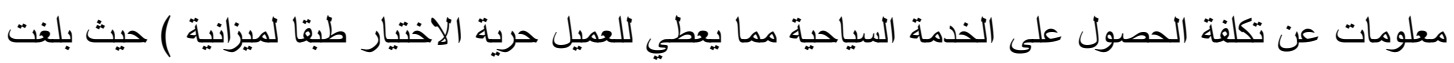

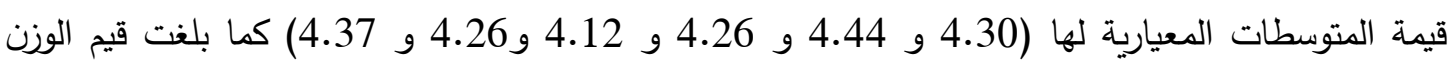

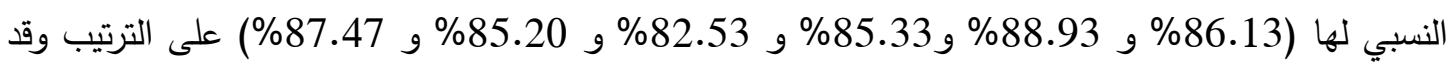

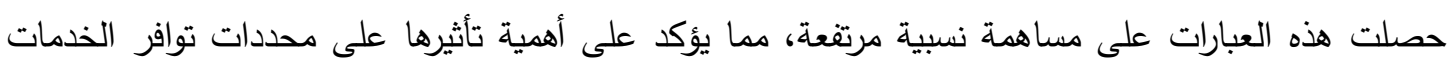

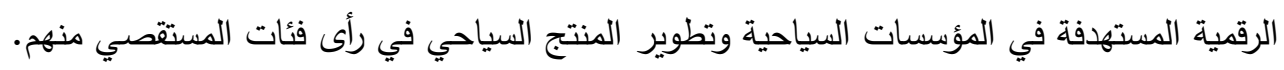
-أوضحت النتائج أيضا وجود استجابات منخفضة بين آراء فئات المستقصى منهم في الفقرات رقم (11)

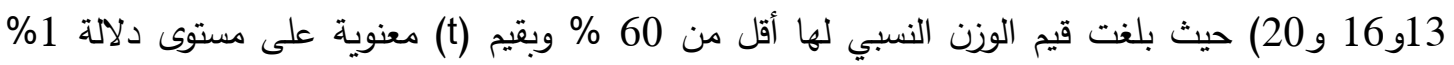

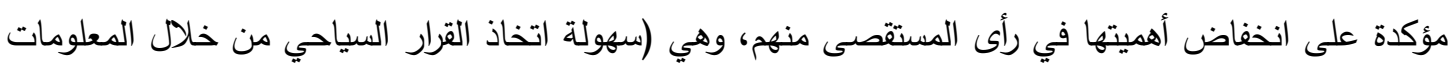
المتوفرة بالموقع والتطبيقات الإلكترونية وسهولة الوصول إلى المواقع الالكترونية السياحية على شبكة الانترنت.

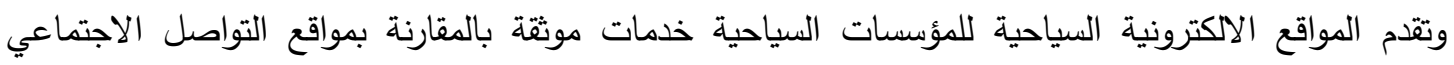

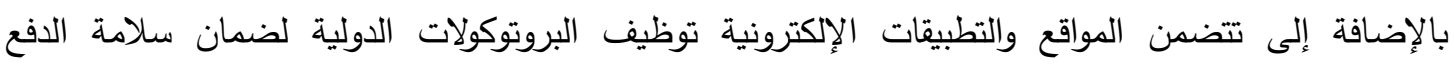

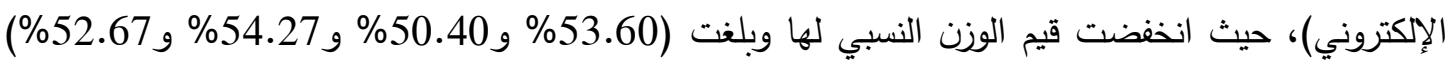

$$
\text { على الترتيب. }
$$

- - - وأكدت النتائج أيضا عدم وجود فقرات ذات استجابة محايدة في محتواها في آراء فئات المستقصي منهم.

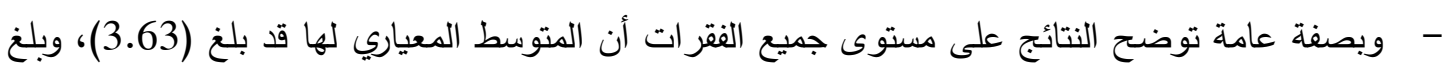

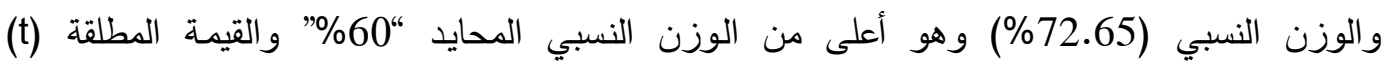

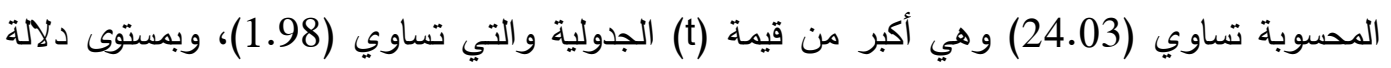

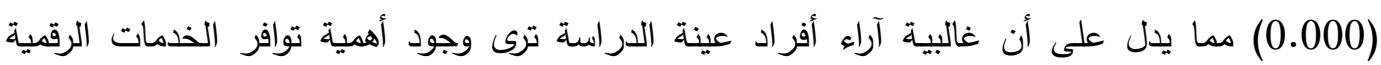

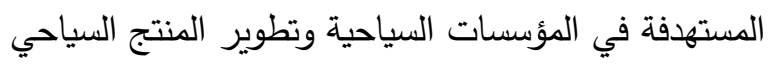


جدول (6) نتائج اختبار t للعينة الواحدة حول محددات توافر الخدمات الرقمية المستهدفة في المؤسسات

\begin{tabular}{|c|c|c|c|c|c|c|}
\hline الأهمية & المعنوية & قيمة t & الوزن & المطأ & المتعياري & الفقرة \\
\hline منخفضة & 0.000 & -4.91 & 53.60 & .06507 & 2.68 & 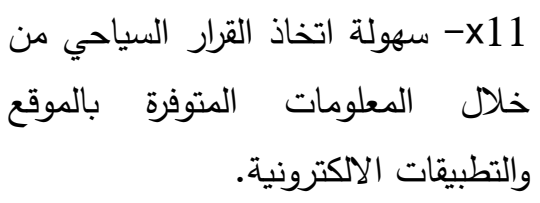 \\
\hline مرتقعة & 0.000 & 22.42 & 86.13 & 0.058 & 4.30 & الالكترونية. \\
\hline منخفضة & 0.000 & -7.05 & 50.40 & 0.068 & 2.52 & 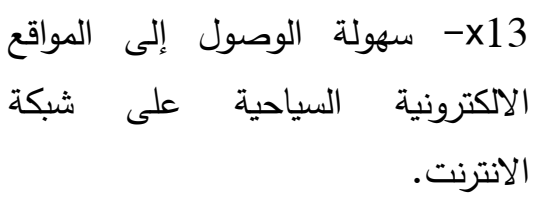 \\
\hline مرتقعة & 0.000 & 19.98 & 88.93 & 0.072 & 4.44 & 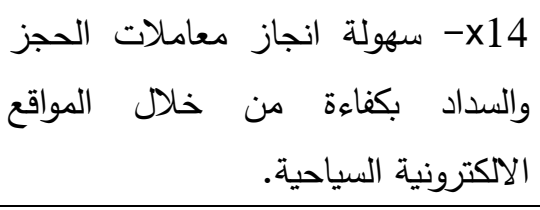 \\
\hline مرتقعة & 0.000 & 15.39 & 85.33 & 0.082 & 4.26 & 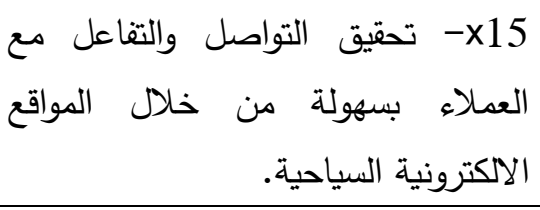 \\
\hline منخفضة & 0.000 & -4.22 & 54.27 & 0.067 & 2.71 & 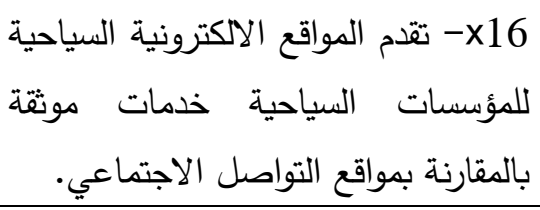 \\
\hline مرتقعة & 0.000 & 14.41 & 82.53 & 0.078 & 4.12 & 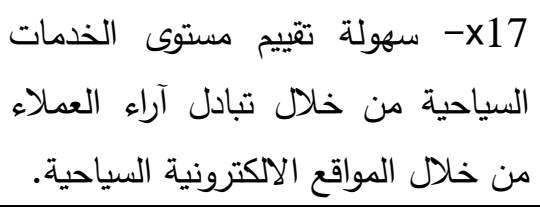 \\
\hline مرتقعة & 0.000 & 17.89 & 85.20 & 0.070 & 4.26 & 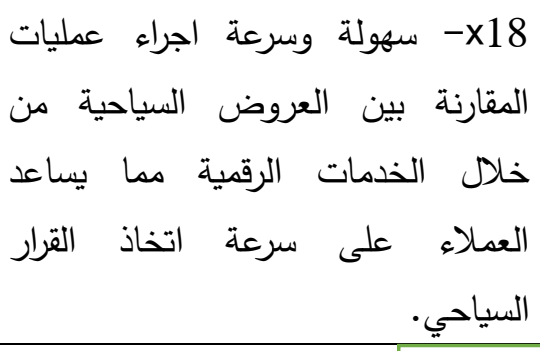 \\
\hline & & & & & & يتبع \\
\hline
\end{tabular}




\begin{tabular}{|c|c|c|c|c|c|c|}
\hline مرتفعة & 0.000 & 21.51 & 87.47 & 0.063 & 4.37 & 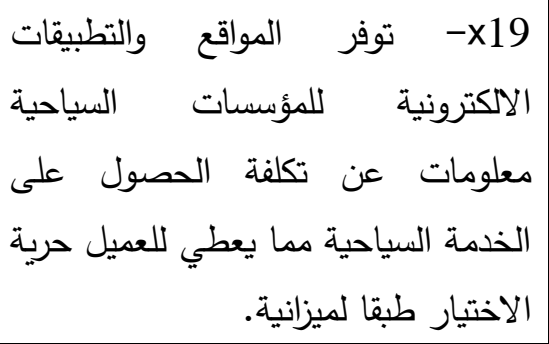 \\
\hline منخفضة & 0.000 & -5.30 & 52.67 & 0.069 & 2.63 & الالكترونية توظيف البروتوكولات الدولية \\
\hline & 0.000 & 24.03 & 72.65 & 0.026 & 3.63 & الإجمالي \\
\hline
\end{tabular}

يوضح جدول (7) نتائج اختبار t للعينة الواحدة حول محددات الصعوبات التي تواجه تطبيق التحول الرقمي في

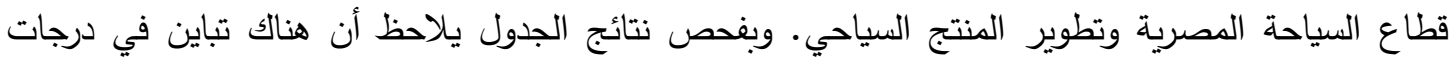
الاستجابة لاى فئات المستقصي منهم حول عبارات الجدول كالآتي: ونطئ

- تميزت عبارات (22 و24 و25 و26) بإيجابية عالية في محتواها في رأى فئات الدستقصي منهم حيث بلغت

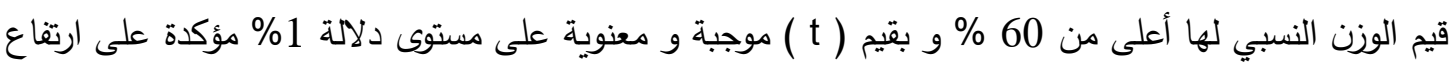

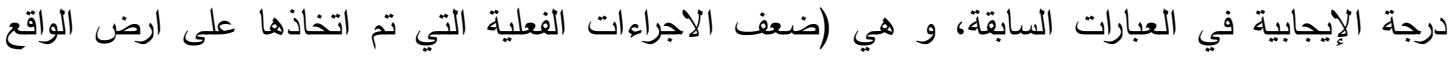

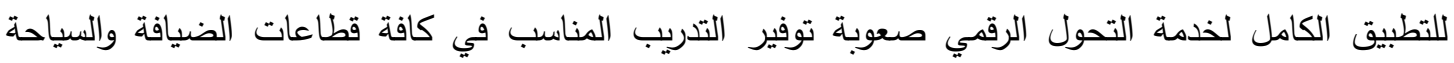

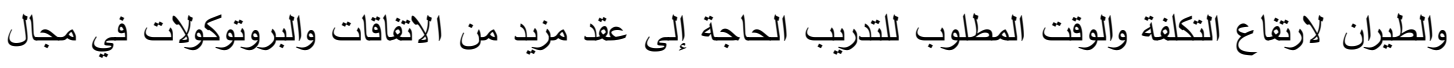

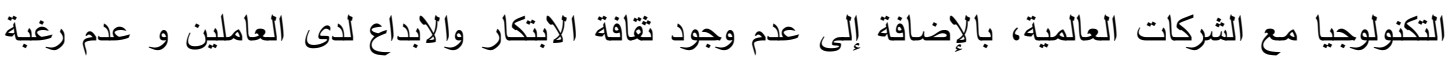

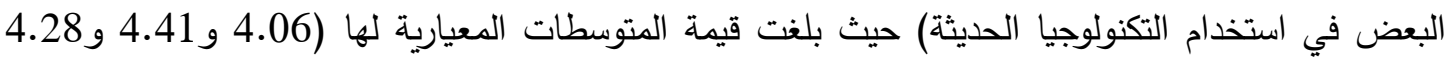

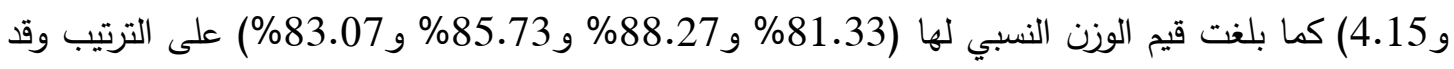

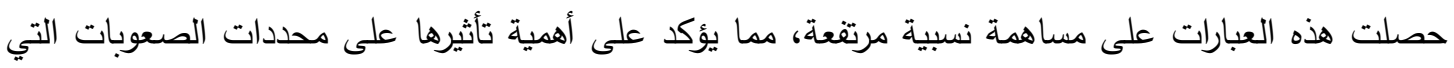

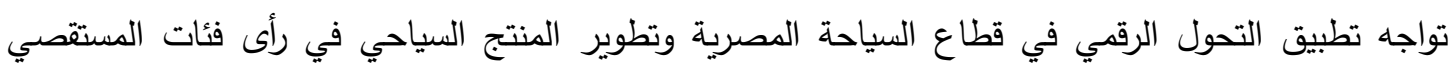

-أوضحت النتائج أيضا وجود استجابات منخفضة بين آراء فئات المستقصي منهم في الفقرات رقم (2و 23)

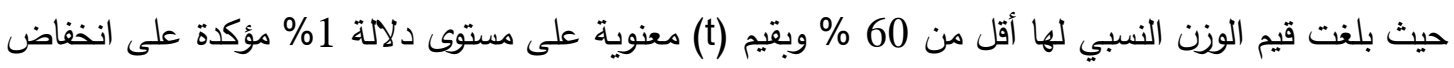

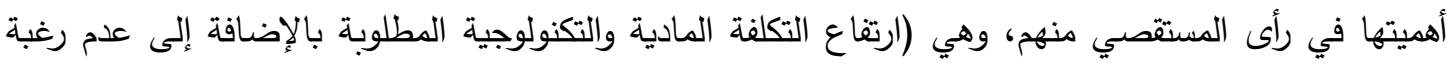

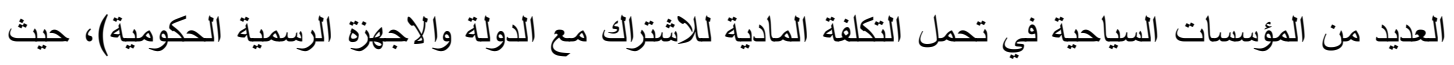

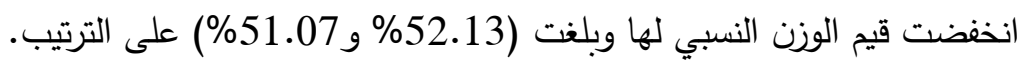

- - مأكدت النتائج أيضا عدم وجود فقرات ذات استجابة محايدة في محتواها في آراء فئات المستقصي منهم. 
- وبصفة عامة توضح النتائج على مستوى جميع الفترات أن المتوسط المعياري لها قد بلغ (3.68)، وبلغ

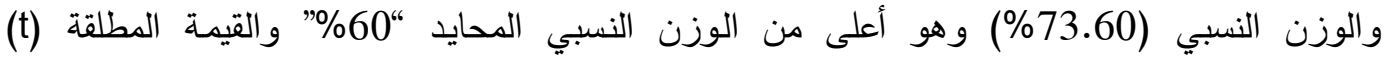
الححسوبة تساوي (20.14) وهي أكبر من قيمة (t) الجدولية والتي تساوي (1.98)، بمستوى دلالة

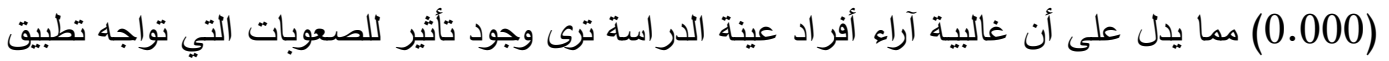
التحول الرقمي في قطاع السياحة المصرية وتطوير المنتج السياحي. جدول (7) نتائج اختبار t للعينة الواحدة حول محددات الصعوبات التي تواجه تطبيق التحول الرقمي في قطاع السياحة المصرية وتطوير المنتج السياحي

\begin{tabular}{|c|c|c|c|c|c|c|}
\hline النسبية & المعنوية & قيمة t & 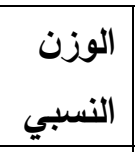 & الغطأ & المتوسط & الفقرة \\
\hline منخفضة & 0.000 & -6.20 & 52.13 & 0.063 & 2.60 & 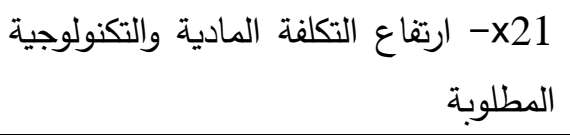 \\
\hline مرتقعة & 0.000 & 16.87 & 81.33 & 0.063 & 4.06 & 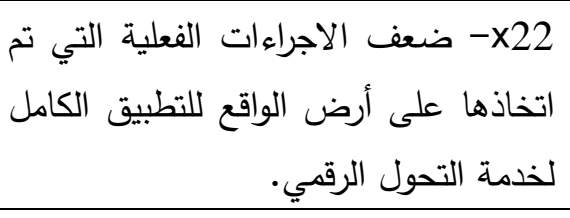 \\
\hline منخفضة & 0.000 & -5.92 & 51.07 & 0.075 & 2.55 & 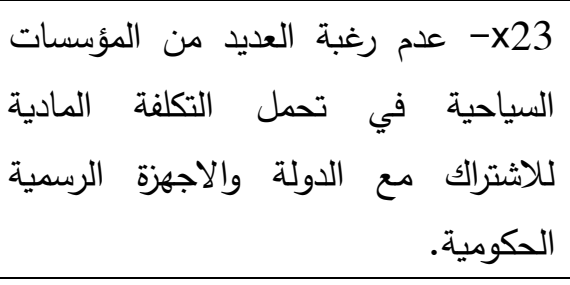 \\
\hline مرتفعة & 0.000 & 23.00 & 88.27 & 0.061 & 4.41 & 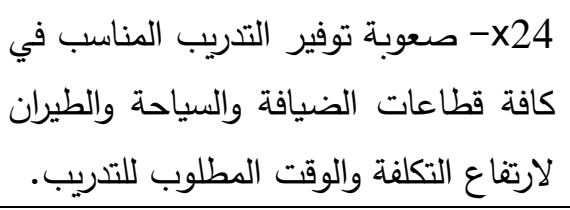 \\
\hline مرتقعة & 0.000 & 19.98 & 85.73 & 0.064 & 4.28 & الثركات العالمية. x25- الحاجة إلى عقد مزيد من الاتفاقات \\
\hline مرتقعة & 0.000 & 15.15 & 83.07 & 0.076 & 4.15 & 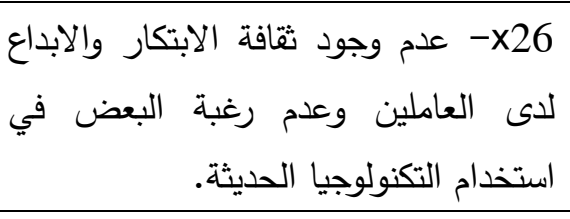 \\
\hline & 0.000 & 20.14 & 73.60 & 0.033 & 3.68 & الإجمالي \\
\hline
\end{tabular}

وترى الباحثتان بناء على النتائج السابقة (جداول 5 و6 و7)، وجود تباين في نوعية الاستجابات للفقرات السابقة

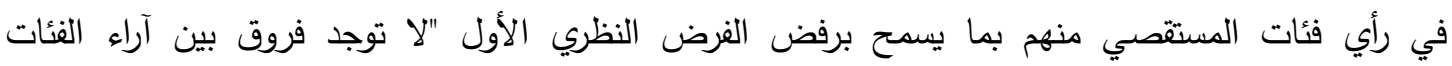


المستقصي منهم حول أهية التحول الرقمي وتطوير المنتج السياحي بهدف زيادة القدرة التتافسية والقيمة الدضافة للقطاع السياحي". ويقبل الفرض البديل.

ويلاحظ من نتائج اختبار T للعينة الواحدة (On sample - T test)، جداول (5 و6 و7) أنه تم تحديد

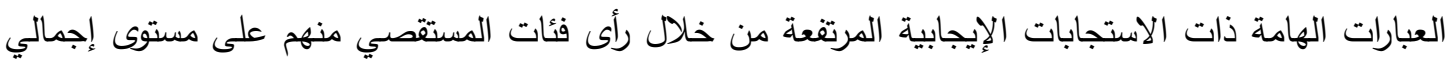

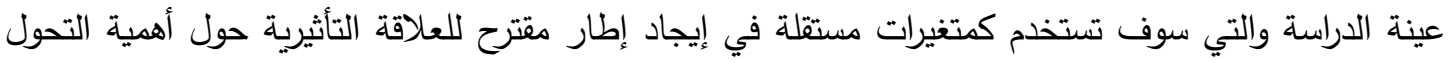

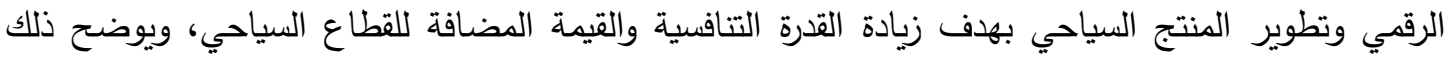

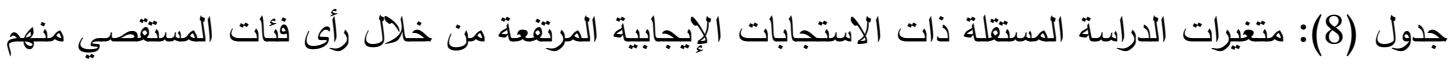
على مستوى إجمالي عينة الدراسة. جدول (8) متغيرات الدراسة المستقلة ذات الاستجابات الإيجابية المرتفعة من خلال رأى فئات المستقصي منهم على مستوى إجمالي عينة الدراسة.

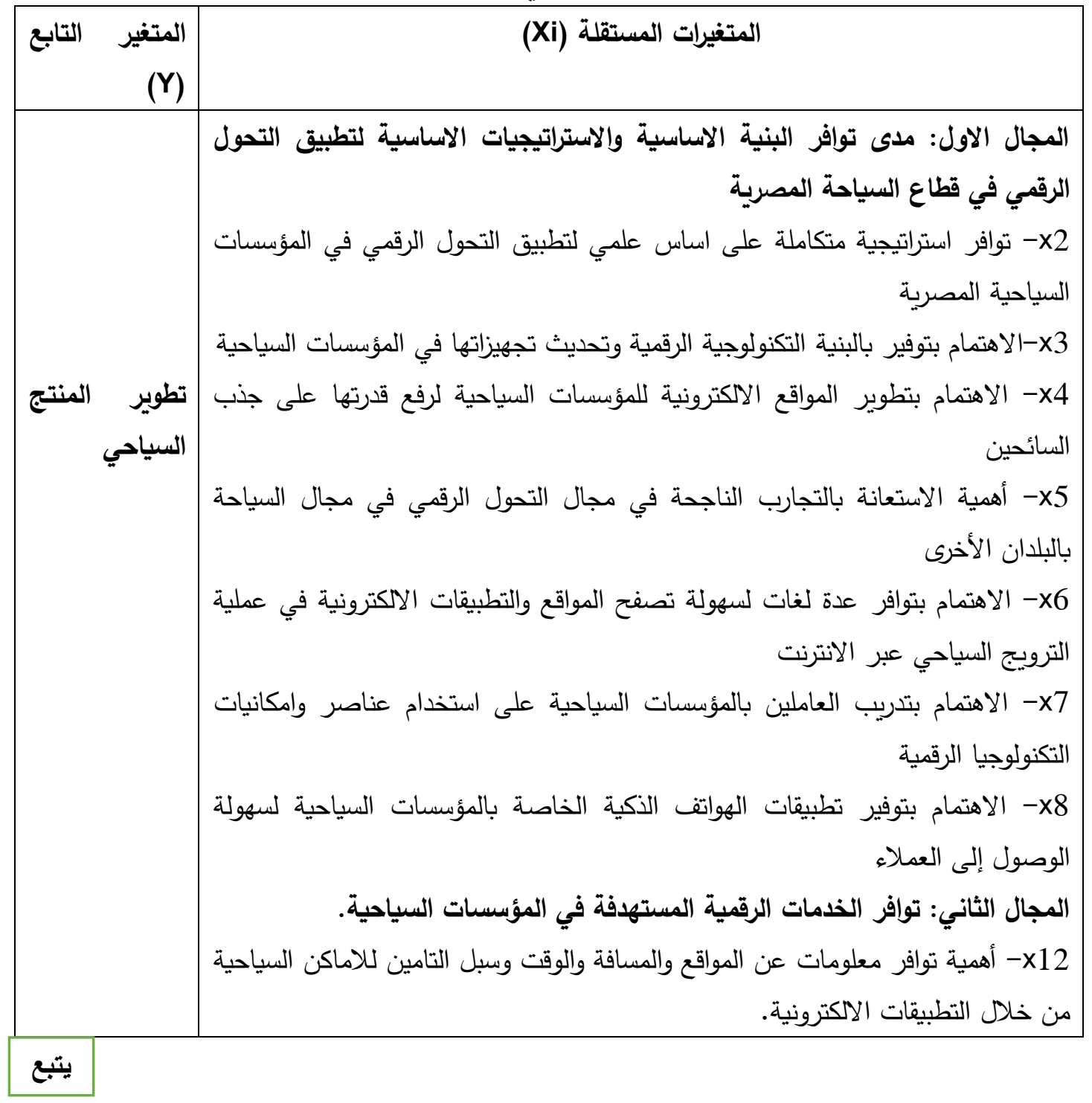




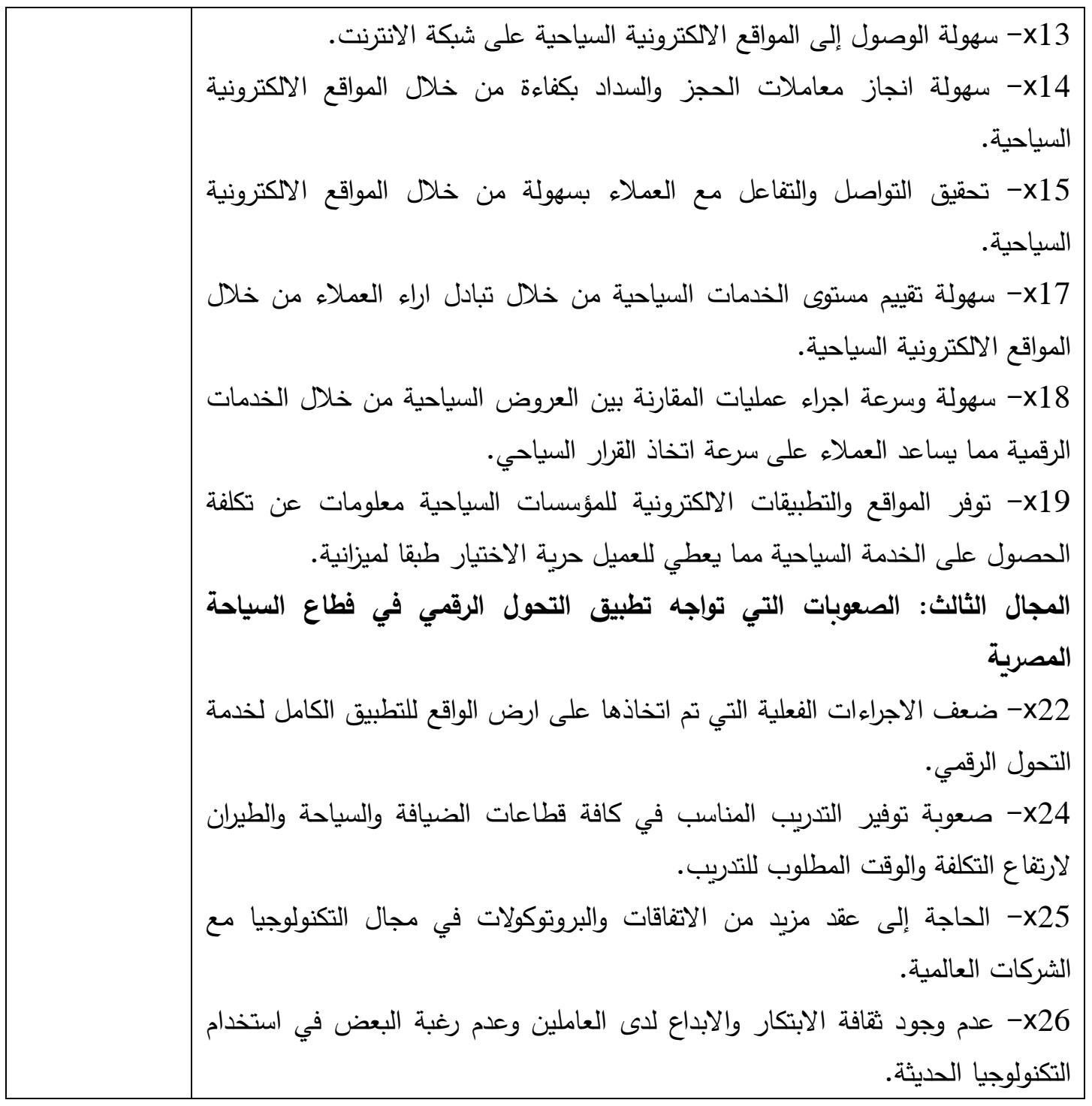

ب- اختبار صحة الفروض الخاصة بتحليل الارتباط (Correlation).

تم استخدام تحليل الارتباط (Correlation) باستخدام معامل ارتباط بيرسون، بالإضافة إلى تقدير المساهمة

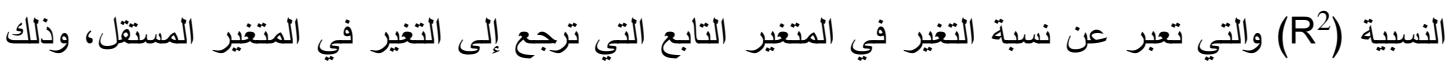
بهدف اختبار جودة العلاقة بين المتغيرات المستخدمة في فروض الدراسة الدئي الديدانية وأظهرت النتائج الاتي: اختبار صحة الفرض الثاني: "لا توجد علاقة ارتباط بين مدى توافر البنية الاساسية والاستراتيجيات الاساسية لتطبيق التحول الرقمي وتطوير المنتج السياحي". 1- تثير النتائج المبينة في جدول رقم (9) أن هناك علاقة إيجابية طردية قوية بين كل من (مدى توافر البنية

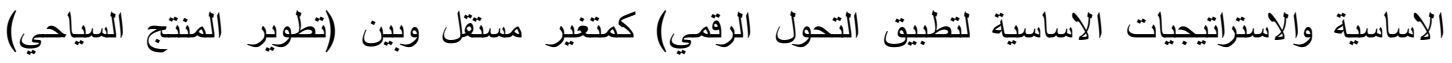

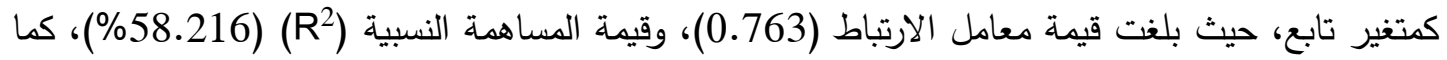


يثير مستوى المعنوية إلى أن هذه العلاقة عالية المعنوية ولا ترجع إلى الصدفة، حيث بلغ مستوى الدلالة

$$
0.05 \text { (0.000) وهي }
$$

2- النتيجة السابقة تعني وجود علاقة ارتباط ذات دلالة إحصائية بين أهمية توافر البنية الاساسية والاستراتيجيات اللازمة لتطبيق التحول الرقمي وبين (تطور المنتج السياحي). جدول (9) علاقة الارتباط بين مدى توافر البنية الأساسية والاستراتيجيات الأساسية لتطبيق التحول الرقمي

\begin{tabular}{|c|c|c|}
\hline تطوير إدارة المنتج السياحي & المعالم الإحصائية & المحور \\
\hline 0.763 & معامل الارتباط (R) & \multirow{4}{*}{ لدالاستراتيجيات الأساسية الاسنية الاساسية } \\
\hline 58.216 & المساهمة النسبية (R2) & \\
\hline 0.000 & مستوى المعنوية & \\
\hline 131 & حجم العينة & \\
\hline
\end{tabular}

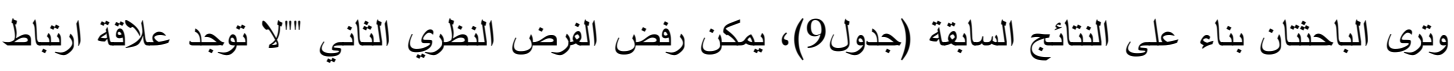
بين مدى توافر البنية الاساسية والاستراتيجيات الاساسية لتطبيق التحول الرقمي وتطوير المنتج السياحي ".

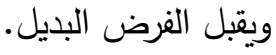

اختبار صحة الفرض الثالث: "لا توجد علاقة ارتباط بين توافر الخدمات الرقمية المستهدفة في المؤسسات السياحية وتطوير المنتج السياحي ". 1- تثير النتائج المبينة في جدول رقم (10) أن هناك علاقة ايجابية طردية قوية بين كل من (توافر الخدمات

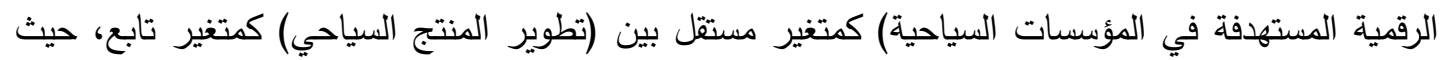

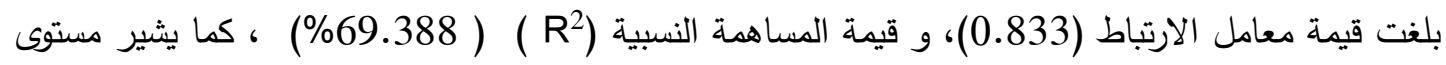

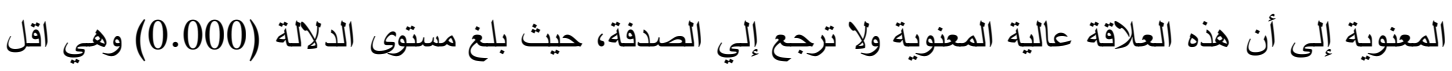
من 0.05

2- النتيجة السابقة تعني وجود علاقة ارتباط ذات دلالة إحصائية بين توافر الخدمات الرقمية الخاصة بمجال السياحة وبين (تطوير المنتج السياحي). جدول (10) علاقة الارتباط بين توافر الخدمات الرقمية الخاصة بمجال السياحة (كمتغير مستقل) وبين تطوير

\begin{tabular}{|c|c|c|}
\hline \multicolumn{3}{|c|}{ المنتج السياحي (كمتغير تابع) } \\
\hline تطوير إدارة المنتج السياحي & المعالم الإحصائية & المحور \\
\hline 0.833 & معامل الارتباط (R) & توافر الخدمات الرقمية \\
\hline 69.388 & المساهمة النسبية (R2) & الخاصة بمجال السياحة \\
\hline 0.000 & مستوى المعنوية & \\
\hline 131 & حجم العينة & \\
\hline
\end{tabular}


وترى الباحثتان بناء على النتائج السابقة (جدول 10)، يمكن رفض الفرض النظري الثالث "لا توجد علاقة ارتباط

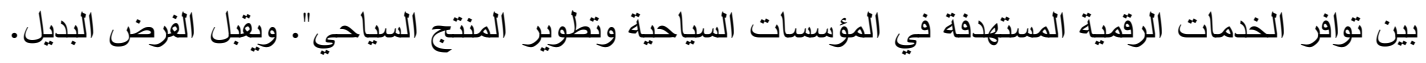
اختبار صحة الفرض الرابع: "لا توجد علاقة ارتباط بين الصعوبات التي تواجه تطبيق التحول الرقمي في السياحة المصرية وتطوير المنتج السياحي. 1- تثير النتائج المبينة في جدول رقم (11) أن هناك علاقة ايجابية طردية قوية بين كل من (الصعوبات التي

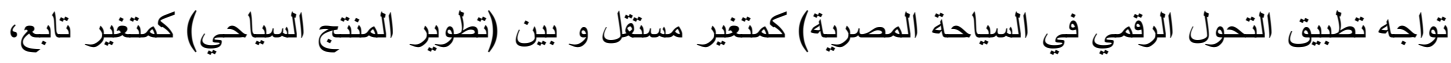

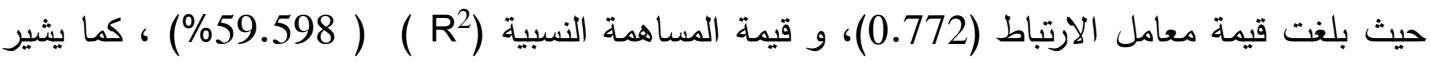
مستوى المعنوية إلى أن هذه العلاقة عالية المعنوية ولا ترجع إلي الصدفة، حيث الكية بلغ مستوى الدلالة (0.000) وهي اقل من 0.05 2- النتيجة السابقة تعني وجود علاقة ارتباط ذات دلالة إحصائية بين أثر الصعوبات التي تواجه تطبيق التحول

$$
\text { الرقمي في السياحة المصرية وبين (تطوير المنتج السياحي). }
$$

جدول (11) علاقة الارتباط بين الصعوبات التي تواجه تطبيق التحول الرقمي في السياحة المصرية (كتغير

\begin{tabular}{|c|c|c|}
\hline تطوير المنتج السياحي & المعالم الإحصائية & المحور \\
\hline 0.772 & معامل الارتباط (R) & \multirow{4}{*}{ 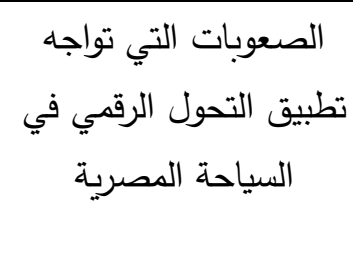 } \\
\hline 59.598 & المساهمة النسبية (R2) & \\
\hline 0.000 & مستوى المعنوية & \\
\hline 131 & حجم العينة & \\
\hline
\end{tabular}

وترى الباحثتان بناء على النتائج السابقة (جدول رقم 11)، يمكن رفض الفرض النظري الرابع: "لا توجد علاقة

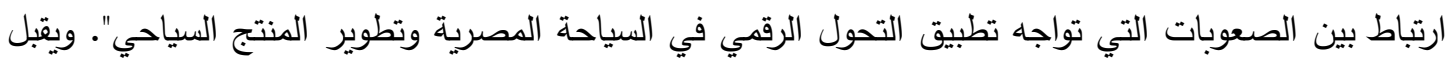

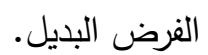

اختبار صحة الفرض النظري الخامس الفرض الخامس:" لا يمكن تتفيذ إطار مقترح للعلاقة التأثيرية بين التحول الرقمي وتطوير المنتج السياحي بهدف

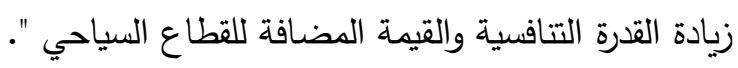

تم استخدام المتغيرات ذات الاستجابات الايجابية وذات المساهمة النسبية المرتفع، والناتجة من اختبار اللعينة

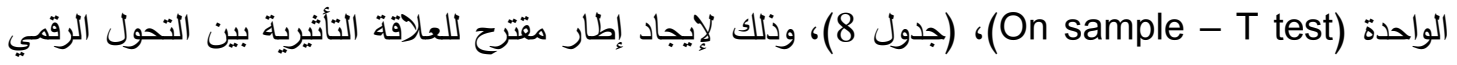

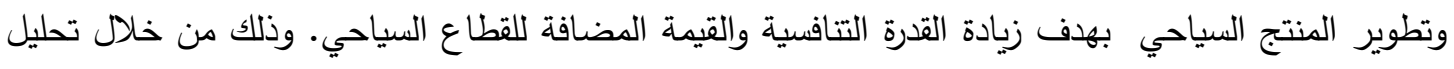
الانحدار المرحلي (Stepwise regression)، حيث تقدر قيم معاملات الانحدار ومعامل الارتباط المتعدد 
ومعاملات الانحدار القياسي الجزئي بالإضافة إلى اختبار الازدواج الخطى بين المتغيرات الناتجة لضمان دقة

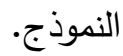

ويوضح جدول (12) نتائج تحليل الانحدار المرحلي لتحديد نموذج لهذه العلاقة، وبفحص نتائج الجدول يلاحظ الأني

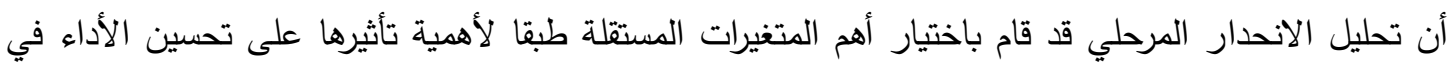

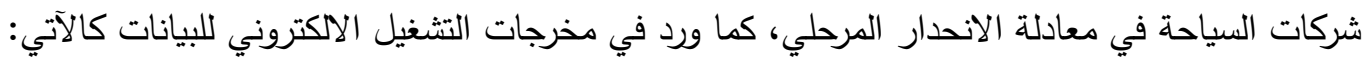
x17- سهولة تقييم مستوى الخدمات السياحية من خلال تبادل آراء العملاء من خلال المواقع الإكترونية

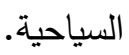

x4 - الاهتمام بتطوير المواقع الإلكترونية للمؤسسات السياحية لرفع قدرتها على جذب السائحين.

x2 توافر استراتيجية متكاملة على أساس علمي لتطبيق التحول الرقمي في المؤسسات السياحية الدصرية. x18- سهولة وسرعة إجراء عمليات المقارنة بين العروض السياحية من خلال الخدات الرقمية مما يساعد العملاء على سرعة اتخاذ القرار السياحي.

x26- عدم وجود ثقافة الابتكار والإبداع لاى العاملين وعدم رغبة البعض في استخدام التكنولوجيا الحديثة. x19- توفر المواقع والتطبيقات الإكترونية للمؤسسات السياحية معلومات عن تكلفة الحصول على الخدمة. x15- تحقيق التواصل والتقاعل مع العملاء بسهولة من خلال المواقع الإلكترونية السياحية. مع استبعاد باقي المتغيرات جدول (11) نتائج تحليل الانحدار المرحلي لتحديد نموذجا للعلاقة بين التحول الرقمي وتطوير المنتج السياحي

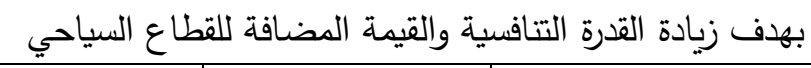

\begin{tabular}{|c|c|c|c|c|c|}
\hline \multirow[b]{2}{*}{ VIF } & \multirow[b]{2}{*}{ ق ق Tيمة T } & \multirow{2}{*}{ 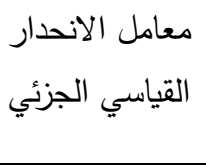 } & \multicolumn{2}{|c|}{ معاملات الانحدار } & \multirow{2}{*}{ الموديل \# } \\
\hline & & & القياسي & الانحدار & \\
\hline--- & 12.974 & --- & 0.118 & 1.527 & ثابت المعادلة \\
\hline 1.172 & 11.983 & 0.482 & 0.010 & 0.124 & الالكترونية السياحية. x17- سهولة تقييم مستوى الخدمات العملاء من خلال المياحية \\
\hline 1.145 & 8.588 & 0.341 & 0.009 & 0.076 & 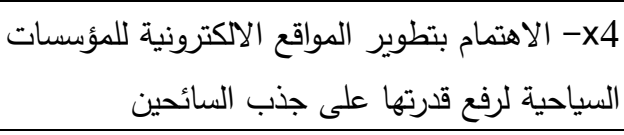 \\
\hline 1.162 & 6.262 & 0.251 & 0.013 & 0.080 & 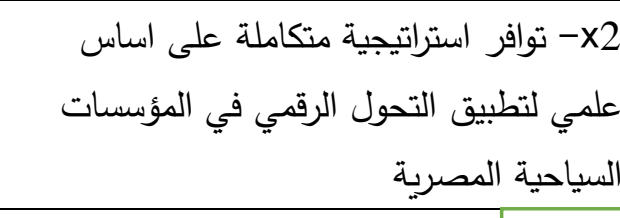 \\
\hline $0 \mid \mathrm{P}$ & & & & & يتبع \\
\hline
\end{tabular}




\begin{tabular}{|c|c|c|c|c|c|}
\hline 1.045 & 9.840 & 0.374 & 0.011 & 0.110 & 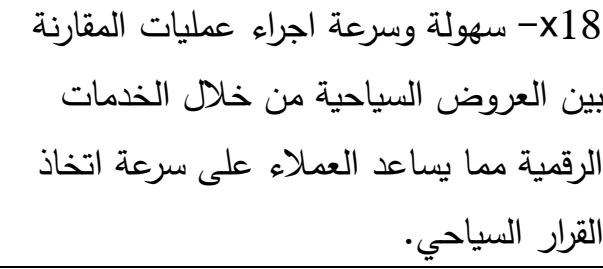 \\
\hline 1.138 & 8.739 & 0.346 & 0.011 & 0.092 & 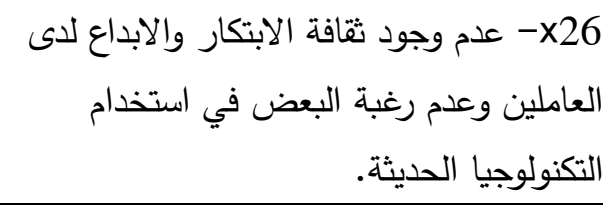 \\
\hline 1.128 & 5.253 & 0.207 & 0.014 & 0.073 & 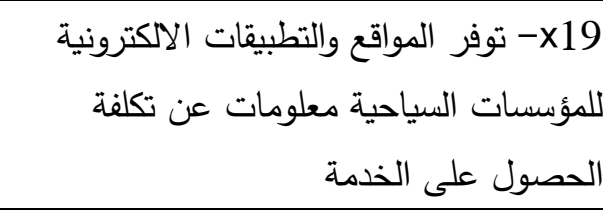 \\
\hline 1.107 & 4.978 & 0.118 & 1.527 & 0.053 & بسهولة من خلال المواقع الالكترونية السياحية. \\
\hline \multicolumn{5}{|c|}{ معامل التحديد (R Square) =85.89\% } & معامل الارتباط المتعدد (R) = 0.9110 \\
\hline
\end{tabular}

. العامل التابع: تطوير المنتج السياحي. (Y)

\# المتغيرات رتبت طبقا لأهميتها النسبية.

يتضح من جدول (11) أيضا أن العلاقة بين التحول الرقمي وتطوير المنتج السياحي بهدف زيادة القدرة التتافسية والقيمة المضافة للقطاع السياحي علاقة طردية وعالية المعنوية حيث بلغت قيم معاملات الانحدار لمتغيرات النموذج (و0.124 و0.076 و0.080 و0.110 و0.092 و0.073 و0.053) على الترتيب. كما لوحظ أن

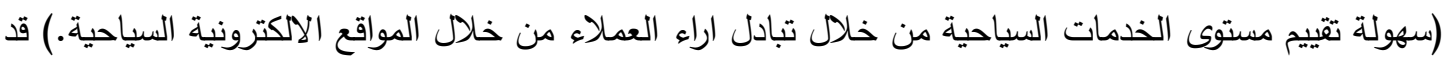

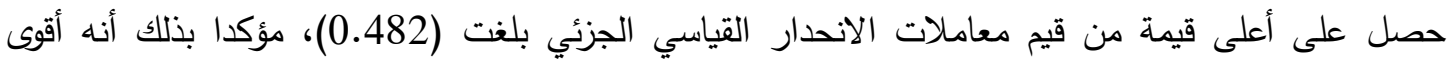
الدتغيرات تأثيرا في تحسين الأداء الإداري بشركات السياحة الدصرية.

وللتأكد من استقلالية متغيرات النموذج مع عدم وجود ارتباط ذاتي في حد الخطأ بين المتغيرات المستقلة (Collinearity Statistics)

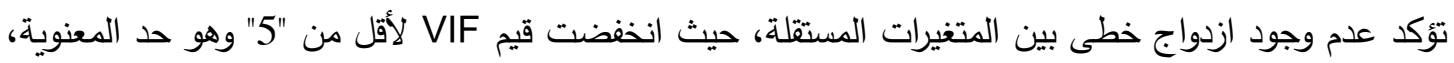
مما يؤكد على صلاحية العلاقة التأثيرية بين التحول الرقمي وتطوير المنتج السياحي بهدف زيادة القدرة التتافسية والقيهة المضافة للقطاع السياحي. وترى الباحثتان أنه يمكن صياغة معادلة النموذج السابق كما يلي: $Y=1.527+0.730 X_{17}+0.092 X_{4}+0.110 X_{2}+0.800 X_{18}+0.760 X_{26}+$ $0.124 \times 19+0.053 X_{15}$

حيث: Y = تطوير المنتج السياحي 
x17- سهولة تقييم مستوى الخدمات السياحية من خلال تبادل آراء العملاء من خلال المواقع الاككترونية

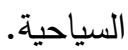

الاهتمام بتطوير المواقع الآكترونية للمؤسسات السياحية لرفع قدرتها على جذب السائحين. x4

x2 توافر استراتيجية متكاملة على اساس علمي لتطبيق التحول الرقمي في المؤسسات السياحية الدصرية. x18- سهولة وسرعة اجراء عمليات المقارنة بين العروض السياحية من خلال الخدمات الرقمية مما يساعد العملاء على سرعة اتخاذ القرار السياحي.

x26- عدم وجود ثقافة الابتكار والابداع لاى العاملين وعدم رغبة البعض في استخدام التكنولوجيا الحديثة. x19- توفر المواقع والتطبيقات الالكترونية للمؤسسات السياحية معلومات عن تكلفة الحصول على الخدمة. x15- تحقيق التواصل والتقاعل مع العملاء بسهولة من خلال المواقع الالكترونية السياحية. كما بلغت قيمة معامل الارتباط المتعدد (R) لمتغيرات النموذج (0.911) ومعامل التحديد (R Square)

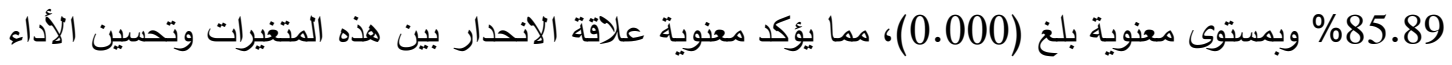
الإداري بشركات السياحة المصرية. ويوضح جدول (12) نتائج تحليل معنوية التباين (ANOVA) لنموذج الانحدار المرحلي بين محددات التحول

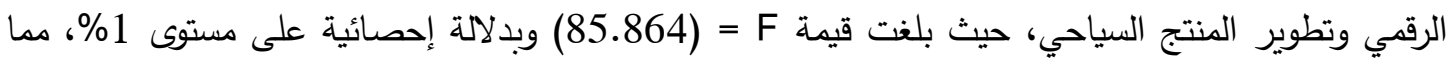

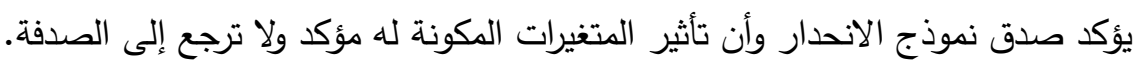
جدول (12) نتائج تحليل معنوية التباين (ANOVA) لنموذج الانحدار المرحلي للعلاقة بين محددات التحول

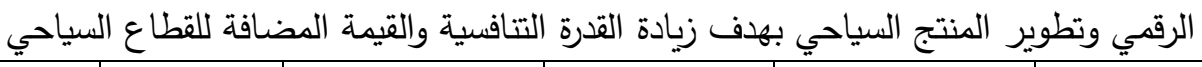

\begin{tabular}{|c|c|c|c|c|c|}
\hline المعنوية & قيمة F & متوسط المربعات & درجات الحرية & مجموع المربعات & مصادر التباين \\
\hline \multirow[t]{3}{*}{0.000} & 85.894 & 1.019 & 7 & 7.135 & الانحدار \\
\hline & & .012 & 123 & 1.460 & الخطأ التجريبي \\
\hline & & & 130 & 8.594 & الكلى \\
\hline
\end{tabular}

النتيجة السابقة تعني وجود علاقة ذات تأثير معنوي بين التحول الرقمي وتطوير المنتج السياحي بهدف زيادة القدرة التتافسية والقيمة المضافة للقطاع السياحي

\section{الإطار المقترح من أهم المتغيرات التنبؤية}

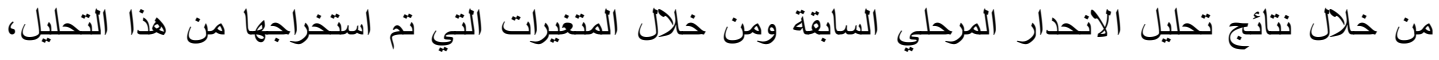

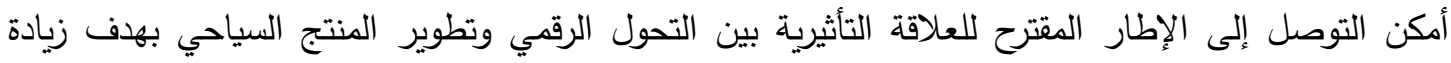
القدرة التنافسية والقيمة المضافة للقطاع السياحي، وتمكنت الباحثتان من تصميم الإطار المقترح، مع تقدير كل لكئل 
من المساهمة النسبية والمساهمة المطلقة لعناصر الإطار المقترح، ويوضح ذلك جدول (13) وشكل (1) كالآتي: جدول (13) الإطار المقترح للعلاقة التأثيرية بين التحول الرقمي وتطوير المنتج السياحي بهدف زيادة القدرة

\begin{tabular}{|c|c|c|c|}
\hline \multicolumn{4}{|r|}{ التتافسية والقيمة المضافة للقطاع السياحي } \\
\hline 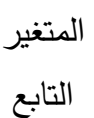 & المطاهمة & النسبية - المة & عناصر الإطار المقترح \\
\hline \multirow{7}{*}{ 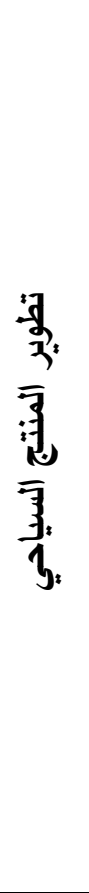 } & \multirow{7}{*}{$\% 88.86$} & \multirow{7}{*}{$\% 85.89$} & 1. سهولة تقييم مستوى الخدمات السياحية من خلال تبادل اراء العملاء من خلال \\
\hline & & & 2. الاهتمام بتطوير المواقع الالكترونية للمؤسسات السياحية لرفع قدرتها على \\
\hline & & & 3. توافر استراتيجية متكاملة على اساس علمي لتطبيق التحول الرقمي في \\
\hline & & & 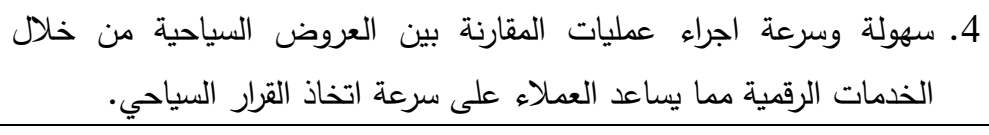 \\
\hline & & & 5. أهمية توافر ثقافة الابتكار والابداع لاى العاملين وعدم رغبة البعض في \\
\hline & & & 6. توفر المواقع والتطبيقات الالكترونية للمؤسسات السياحية معلومات عن تكلفة \\
\hline & & & 7. العمل على تحقيق التواصل والتناعل مع العملاء بسهولة من خلال المواقع \\
\hline
\end{tabular}




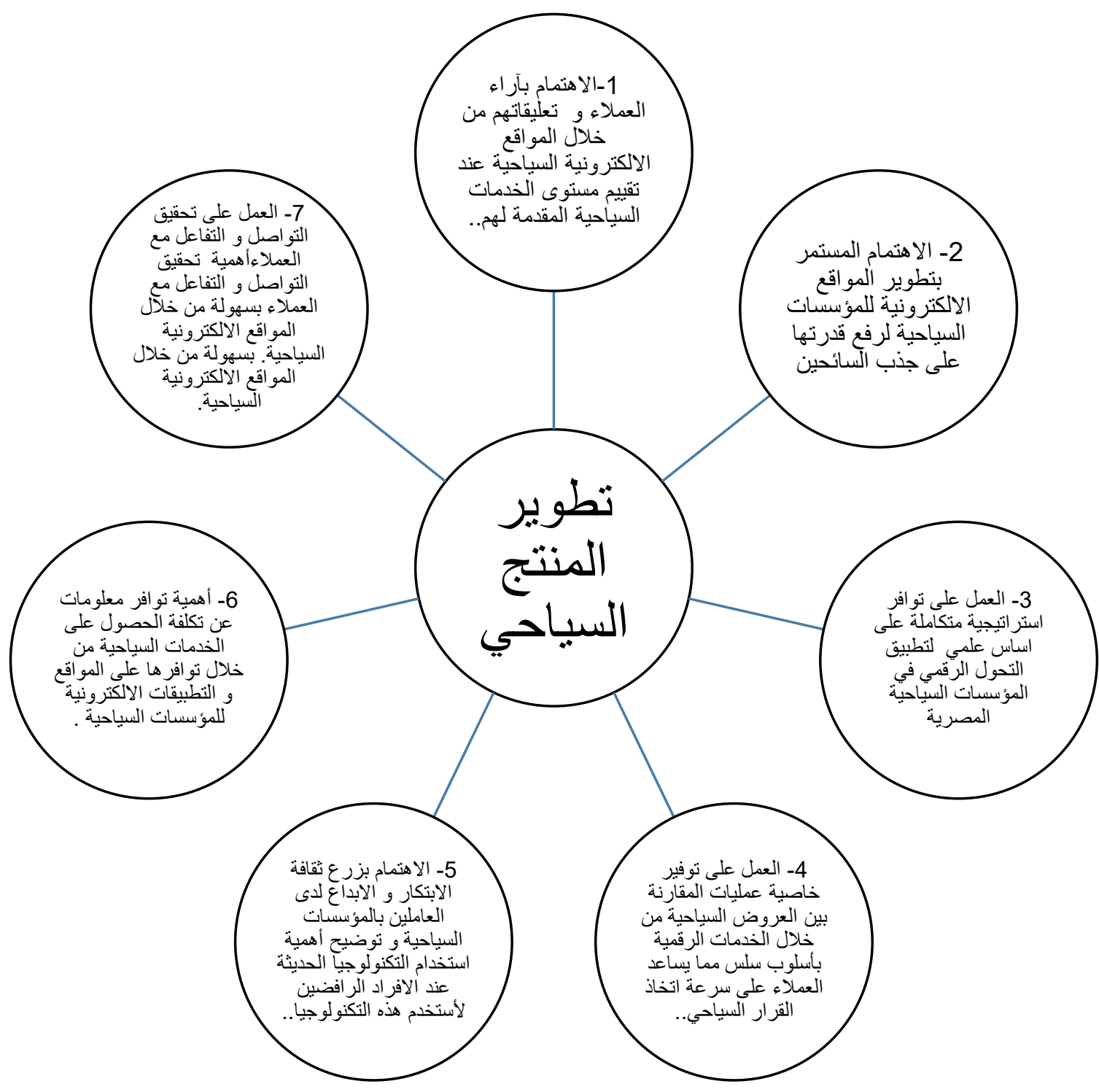

شكل (1) الإطار المقترح للعلاقة التأثيرية بين التحول الرقمي وتطوير المنتج السياحي بهاف زيادة القدرة

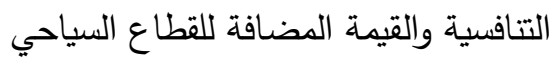

وترى الباحثتان من خلال النتائج العابقة انه يمكن رفض الفرض النظري الخامس: " لا يمكن تتفيذ إطار مقترح

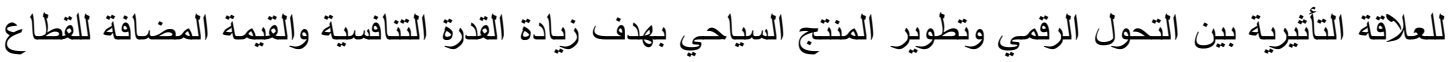
السياحي ". ويقبل الفرض البديل.

9- ن أنتائج الدراسة

1- أكلت النتائج أن أداة الدراسة اليدانية (استمارة الاستقصاء) كانت على درجة عالية من الصدق والثبات مما

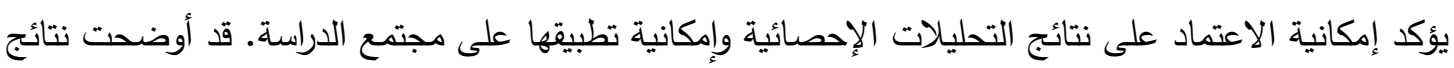


اختبار التوزيع الطبيعي لبيانات الاستقصاء أن محتوى محاور الاستبيان تتبع التوزيع الطبيعي مما يؤكد صلاحية أقسام استمارة الاستبيان لإجراء التحليل الإحصائي عليها.

3- أظهرت النتائج أن غالبية آراء أفراد عينة الدراسة ترى وجود أهمية لمحدات توافر البنية الأساسية

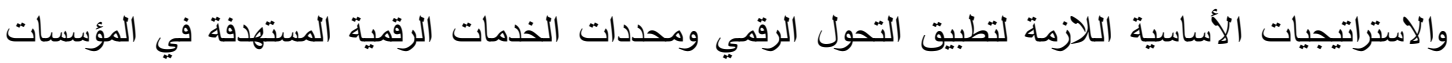
السياحية بالإضافة إلى أهمية العمل على إزالة الصعوبات التي تواجه تطبيق التحول الرقمي في السياحة المصرية وتطوير المنتج المياحي بالإنة الهية

4- أوضحت نتائج الدراسة وجود علاقة ارتباط ذات دلالة إحصائية بين أهمية توافر البنية الأساسية والاستراتيجيات اللازمة لتطبيق التحول الرقمي وبين (تطور المنتج السياحي). وكنلك وجود علاقة ارتباط ذات التات

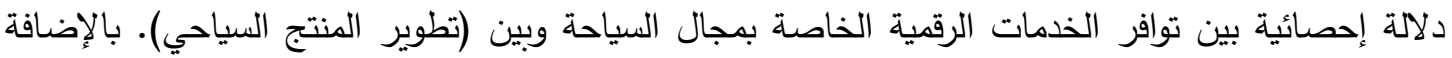

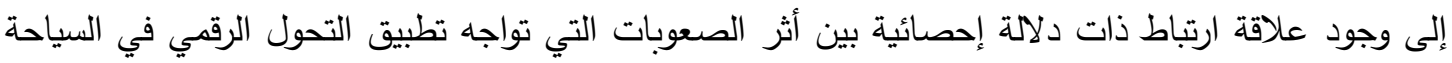
المصرية وبين (تطوير المنتج السياحي).

5- أكدت نتائج تحليل الانحدار المتعدد المرحلي أن هناك أهمية للتحول الرقمي في تطوير المنتج السياحي بهدف زيادة القدرة التتافسية والقيمة المضافة للقطاع السياحي من خلال الاهتمام بالمتغيرات التالية: أ- الاهتمام بآراء العملاء وتعليقاتهم من خلال المواقع الإلكترونية السياحية عند تقييم مستوى الخدمات السياحية المقدمة لهم.

ب- الاهتمام المستمر بتطوير المواقع الإلكترونية للمؤسسات السياحية لرفع قدرتها على جذب السائحين. ج- - العمل على توافر استراتيجية متكاملة على أساس علمي لتطبيق التحول الرقمي في المؤسسات السياحية

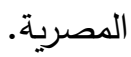

د- العمل على توفير خاصية عمليات المقارنة بين العروض السياحية من خلال الخدمات الرقمية بأسلوب سلس مما يساعد العملاء على سرعة اتخاذ القرار السياحي.

هـ - الاهتمام بزرع ثقافة الابتكار والإبداع لدى العاملين بالمؤسسات السياحية وتوضيح أهمية استخدام

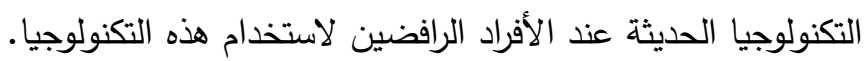
و - أهمية توافر معلومات عن تكلفة الحصول على الخدمات السياحية من خلال توافرها على المواقع والتطبيقات الإكترونية للمؤسسات السياحية. ز - أهمية تحقيق التواصل والتفاعل مع العملاء بسهولة من خلال المواقع الإكترونية السياحية. 
10 - توصيات الدراسة

في ضوء الإطار النظري للدراسة والنتائج التي توصلت إليها تقدم الباحثتان التوصيات التالية: 1- ضرورة وضع استراتيجيات ذات طابع حديث لتحقيق التحول الرقمي في كل من الوزارات المسئولة عن

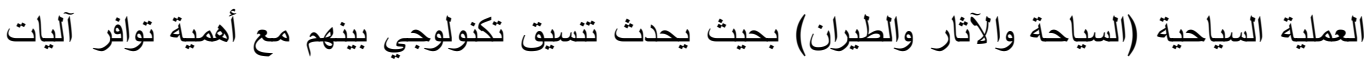
مشتركة وتعاون مع القطاع الخاص والمستثمرين في مجال السياحة وتكنولوجيا المعلومات. 2- الاستفادة بتجارب الدول المتقدمة في نظم السياحة الرقمية في العالم بصفة عامة وفي البلاد العربية بصفة

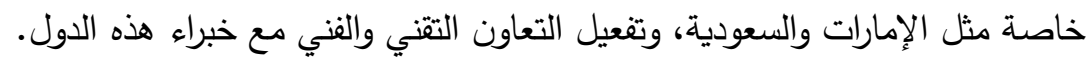
3- العمل على إيجاد كوادر بشرية ذات مستوى عال في مجال الذكاء الاصطناعي والتحول الرقمي من خلال

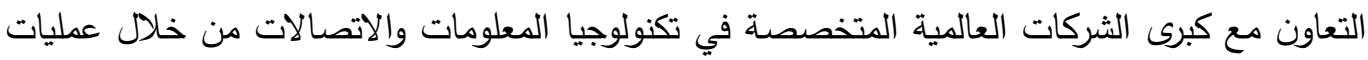

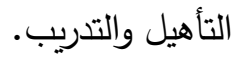

4- قيام الدولة بدعم استراتيجيات التسويق الإكتروني السياحي لدعم الأسواق السياحية الحالية والمرتقبة لتتمية

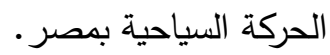
5- الاهتمام بالتحول نحو إنثاء نمط القرى السياحية الذكية التي تعتمد في جميع خذماتها على عمليات

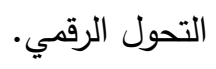
6- العمل على توافر وتعزيز الأمن الإلكتروني لمواجهة المخاطر والهجمات الإلكترونية المحتملة التي يوجهها

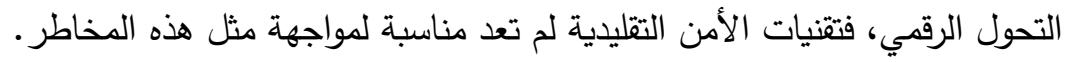

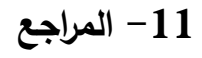
المراجع العربية - - البار، عدنان (2018)، تقنيات التحول الرقمي، كلية الحاسبات وتقنية المعلومات، جامعة الملك عبد العزيز، السعودية. - - بظاظو، ابراهيم (2018): تقنيات الذكاء الاصطناعي في صناعة السياحة الدولية، كلية السياحة والفندقة، الجامعة الاردنية فرع العقبة، الاردن.

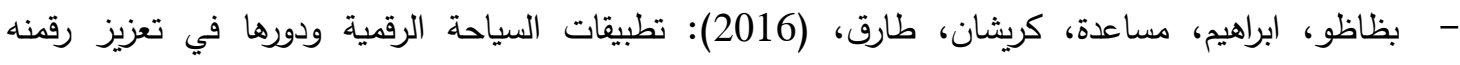

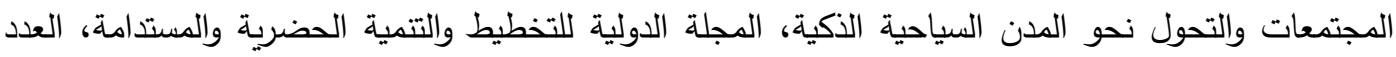

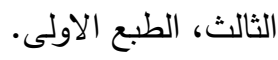
- بن علية سميرة، سالمي عبد المجيد، (2019): " التطبيقات الالكترونية السياحية "، مجلة ألف للغات والاعلام

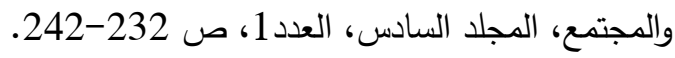
- - جميلة سلامى، يوسف لبوشى (2019) "التحول الرقمي بين الضرورة والمخاطر" - مجلة العلوم القانونية

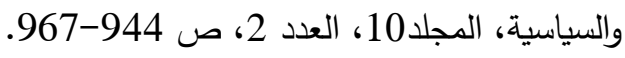


- حسنية بن رقية، (2021): "صعوبات التحول إلى السياحة الذكية في الجزائر" مجلة تطوير العلوم الاجتماعية 2021 (01) 14 (102،90)

حسنية بن رقية، (2021): "صعوبات التحول إلى السياحة الذكية في الجزائر "مجلة تطوير العلوم الاجتماعية 2021 (01) 14 (102،90) - - دبوسى، ربيع (2015)، التحول الرقمي: حقبة الانترنت - الاشياء تحقق مزايا ضخمة، سيسكو الأمارات

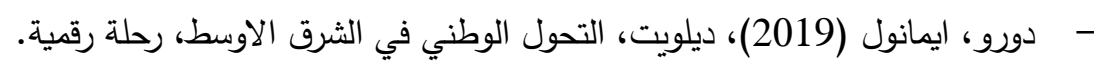

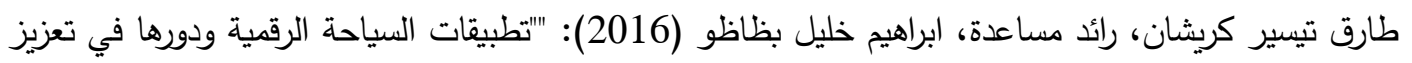

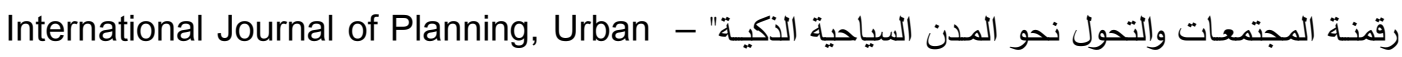
and Sustainable Development, Vol 3 Issue 1, 2016 عبادي محمد وزهواني عبد الرزاق (2019) "تجليات التحول الرقمي ودوره في تغعيل السياحة الداخلية"، مجلة

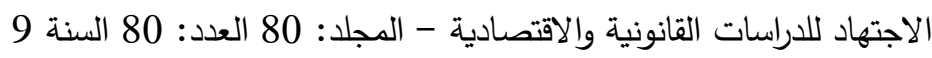
عبد السميع صبري، (2007): التسويق السياحي والفندقي أسس علمية وتجارب الفاب عربية، د.ط. القاهرة: منشورات المنظمة العربية للتنمية الادارية، مصر . غادة على عبد المعطي محمد (2019) " التحول الرقمي في السياحة المصرية (المفهوم - التحديات -

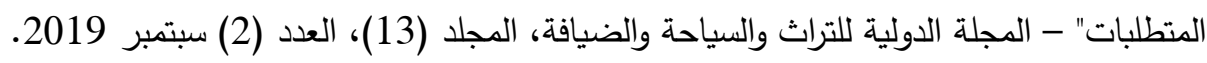

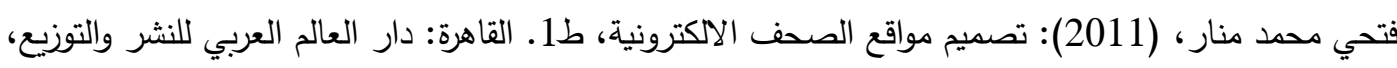
مصر

محمد بن ذهبية، مبروك محمد البشير، (2015): " أثر الدفع الإلكتروني على تتمية اقتصاديات السياحة

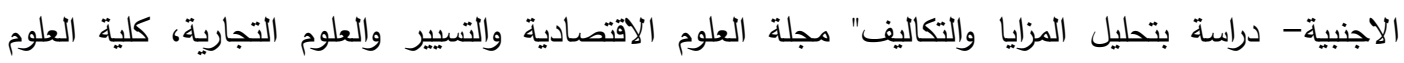

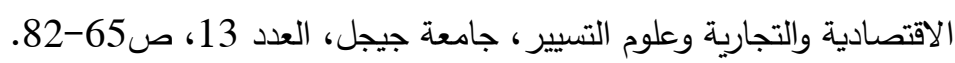

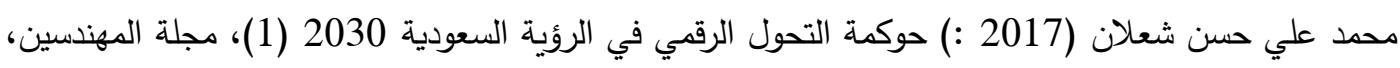

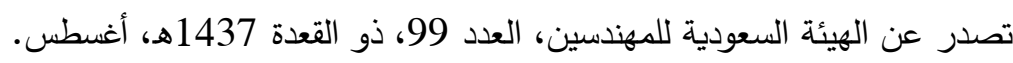
- محد وشاح الوشاح (2021) "لدور التسويق السياحي الإكتروني وأثره على تلتمية القطاع السياحي الأردني" -

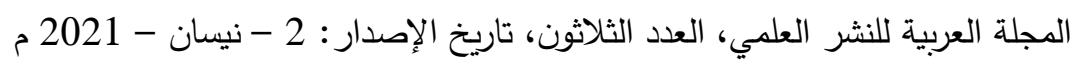

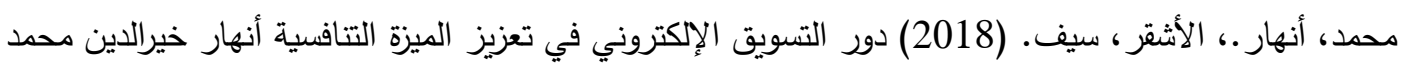

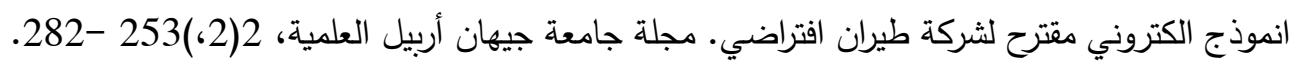

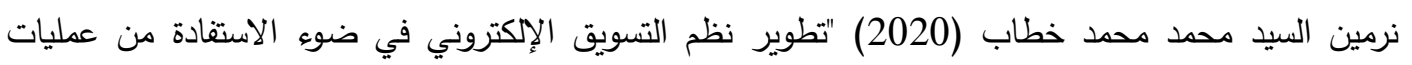

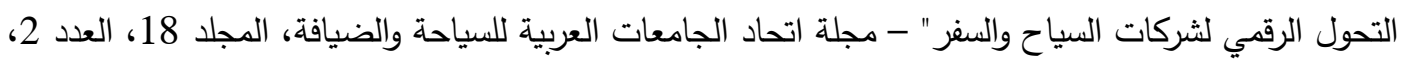

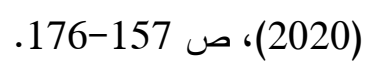

المراجع الاجنبية

- Afaneh, S. M. (2021). E-TOURISM, ITS PROSPECTS" SCOPES" AND IMPACT ON THE DEVELOPMENT OF TOURISM INDUSTRY (THE JORDANIAN 
EXPERIENCE). PalArch's Journal of Archaeology of Egypt/Egyptology, 18(4), 1897-1911.

- Alsarayreh, M. N., \& Salt, J. (2018). Technology and marketing tourism and hotels in Jordan. International Journal of Humanities, Arts and Social Sciences, 4(5), 213-220.

- Baytona. N, (2019), World Tourism Organization, Innovation and Digital Transformation 21-Strategy, Spain.

- Bartlett, J., Kotrlik, J. and Higgins, Ch. 2001. Organizational Research: Determining Appropriate Sample Size in Survey Research, Information Technology, Learning, and Performance Journal, 19(1): 43-50.

- Brysch.A, (2019), Digital Transformation in the Tourism Sector challenges and Opportunities, University of Seville, Spain. Development Perspective in Two Unrelated Companies. International Journal of Novel

- Kumar, B. (2016). Digital Revolution in The Mauritian Public Service. A Human Resource

- Labanauskaitėa, D. Fioreb, M. and Stašysa, R. (2020). Use of E-marketing tools as communication management in the tourism industry. Tourism Management Perspectives Volume 34, April,.1-8. Research in Interdisciplinary Studies Vol. 3, Issue (5), 1-10.

- Snedecor, G.W. and Cochran, W.G. (1980). Statistical methods. Oxford \& J.BH Publishing com. 7th. Edition

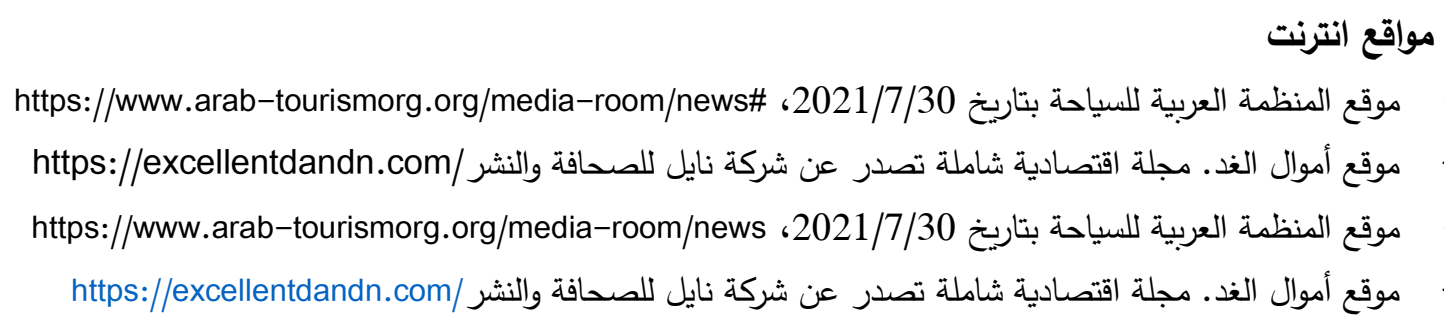

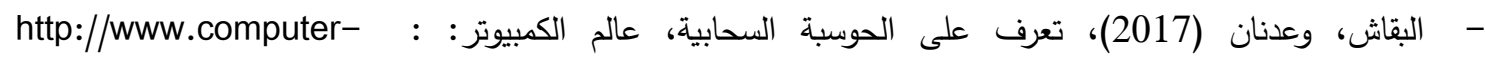
.(wd.com/2017/03/Cloud-Computing-info.html, (Accessed on: 25-2-2018 سالي طه، (2021): "أثر التحول الرقمي. على مستثبل السياحة في مصر ." مقال منشور على موقع دار الهلال بتاريخ

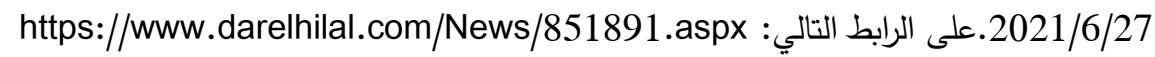
فؤاد منصوري، الددن الذكية في الجزائر.. بين التصور والواقع!، مقال منشور على موقع اخبار الوطن بتاريخ

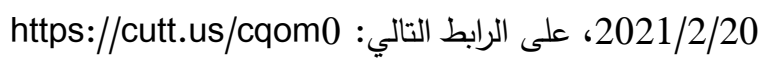

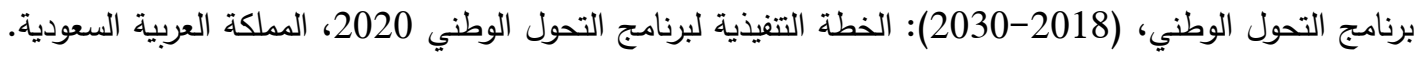
https://vision2030.gov.sa/ar/programs/NTP(Accessed on: 15-9-2018:

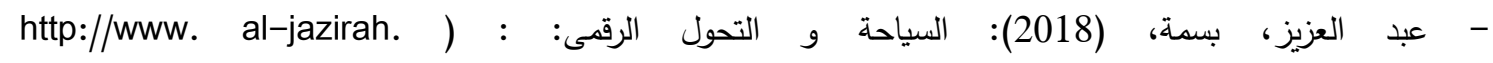
.(com/2018/20180914/sy5. htm, (Accessed on:15-12- 2018

- https://www.cisco.com/c/ar_ae/about/blogs/2015-11-05.html, (Accessed on: 4-12-2019

- https://www2.deloitte.com/content/dam/Deloitte/xe/Documents/technologymediatelecommunications/dtme_tmt_national-transformation-inthemiddleeast/National\%20Transformation\%20in\%20ME\%20-

\%20A\%20Digital\%20Journey\%20-\%20AR.pdf, (Accessed on:1-4-2019) 
استمارة الاستبيان

\begin{tabular}{|c|c|c|c|c|c|}
\hline غير موافق & غوافق & محايد & موافق & 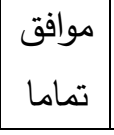 & الفقرة \\
\hline \multicolumn{6}{|c|}{ المجال الاول: مدى توافر البنية الاساسية والاستراتيجيات الاساسية لتطبيق التحول الرقمي في قطاع السياحة المصرية } \\
\hline & & & & & 1- المسؤولين عن إدراك الهمية التحول الرقمي في مجال السياحة من قبل \\
\hline & & & & & 20 في المؤسسات الستراتيجية متكاملة على المصاس علمي لتطبيق التحول الرقمي \\
\hline & & & & & 3-الاهتمام بتوفير بالبنية التكنولوجية الرقمية وتحديث تجهيزاتها في \\
\hline & & & & & 4- الاهتمام بتطوير المواقع الآكترونية للمؤسسات السياحية لرفع قدرتها \\
\hline & & & & & 5- أهمية الاستعانة بالتجارب الناجحة في مجال التحول الرقمي في \\
\hline & & & & & 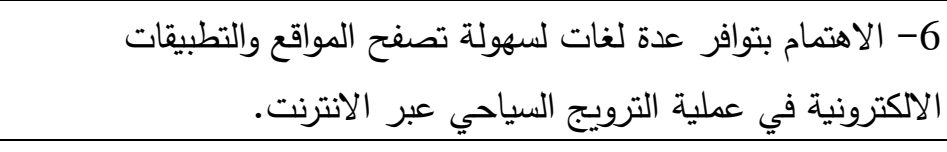 \\
\hline & & & & & 7- الاهتمام بتدريب العاملين بالمؤسسات السياحية على استخدام \\
\hline & & & & & 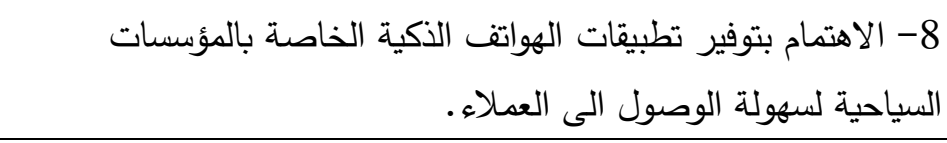 \\
\hline & & & & & 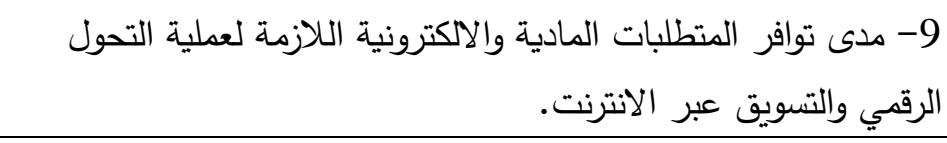 \\
\hline & & & & & 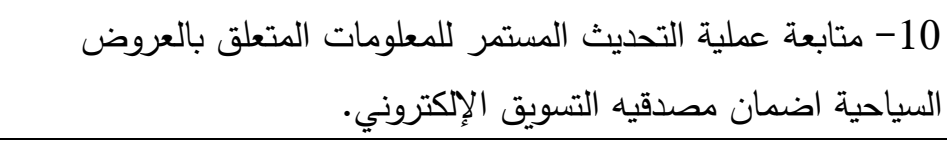 \\
\hline \multicolumn{6}{|r|}{ المجال الثاني: توافر الذدمات الرقمية المستهدفة في المؤسسات السياحية. } \\
\hline & & & & & 11 - سهولة اتخاذ القرار السياحي من خلال المعلومات المتوفرة بالموقع \\
\hline & & & & & 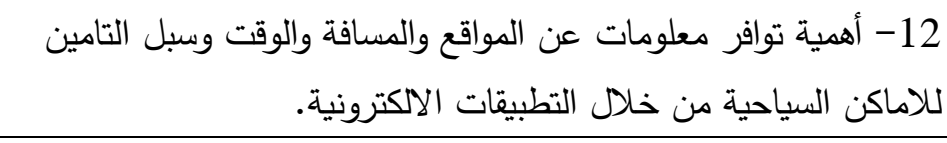 \\
\hline & & & & & الانترنت. سهولة الوصول الى المواقع الآكترونية السياحية على شبكة \\
\hline
\end{tabular}




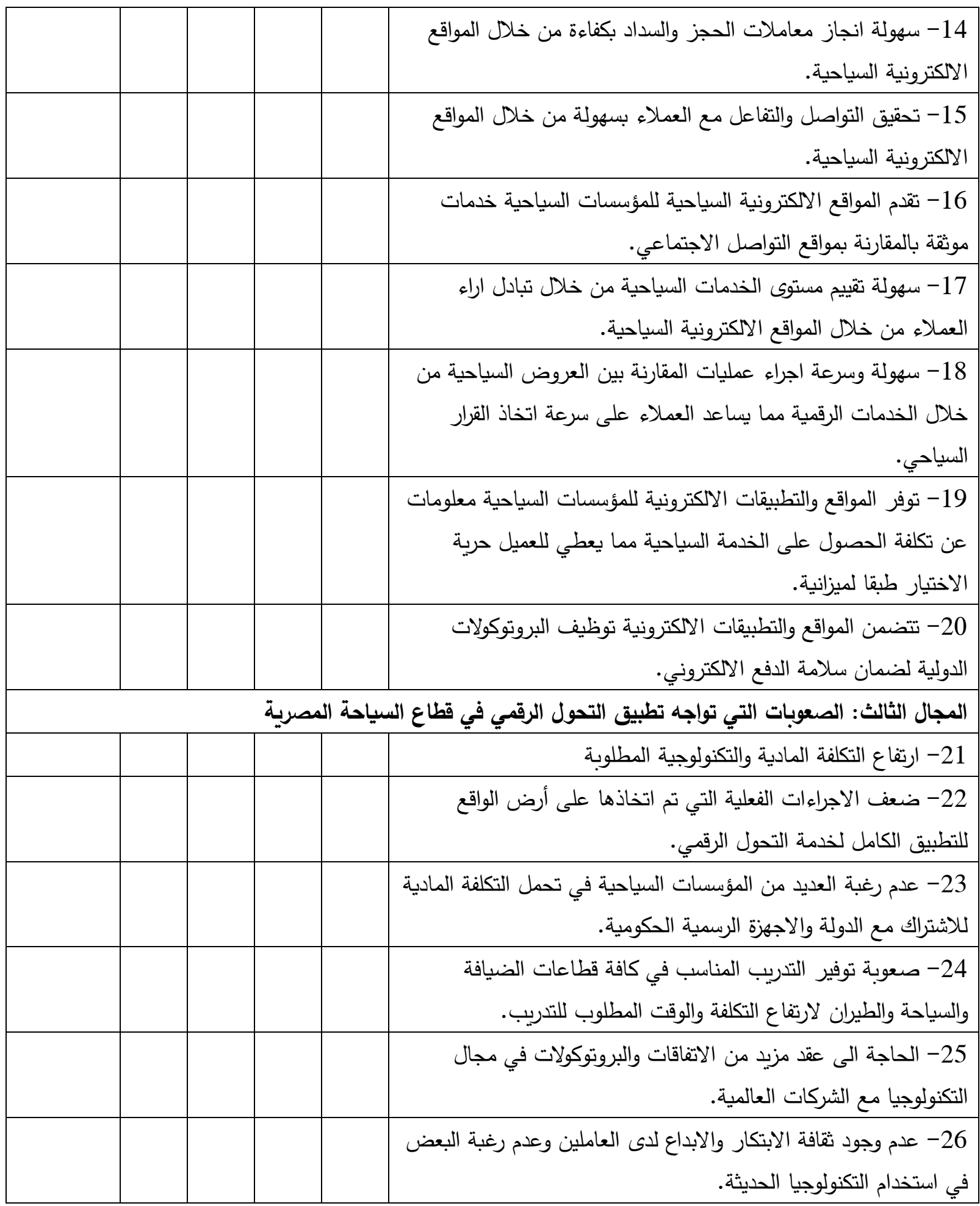




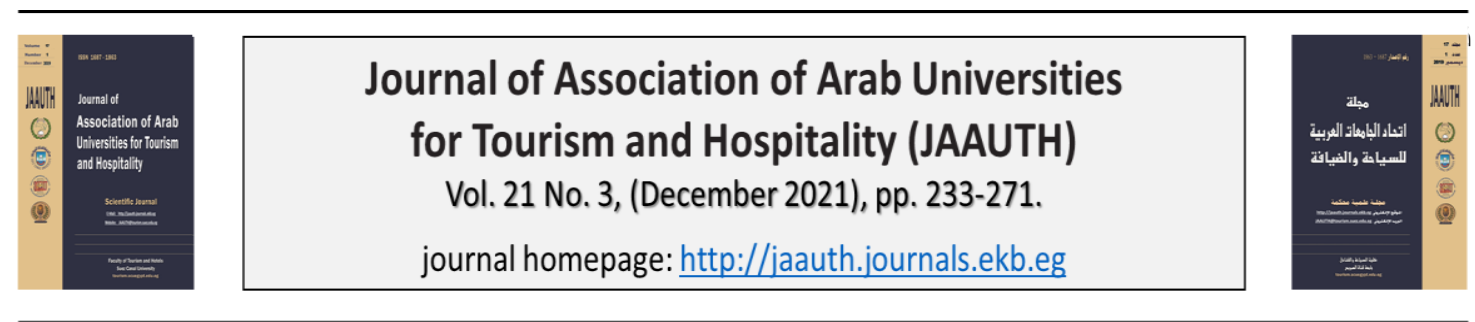

\title{
Impact of Digital Transformation on The Competitiveness and Added Value of the Tourism Sector
}

\author{
Nahla Abdel Wahab Mashhour \\ Lecturer, Tourism Studies Department \\ Higher Institute for Specific Studies
}

Samah Abdel Hafiz Youssef

Lecturer, Tourism Studies Department

Higher Institute for Specific Studies

\begin{tabular}{l}
\hline ARTICLE INFO \\
\hline Keywords: \\
Digital \\
transformatio; \\
tourism product; \\
competitiveness; \\
added value.
\end{tabular}

(JAAUTH)

Vol. 20, No. 3, (December 2021),

PP. 233-271.

\section{ABSTRACT}

This study aims to highlight the importance of digital transformation on the development of the tourism product and its impact on the development of the Egyptian tourism sector in order to find a proposed framework for the impact relationship between digital transformation and the development of tourism product management in order to increase the competitiveness and added value of the tourism sector. The study relied on the descriptive approach, in addition to the deductive approach: where the researcher used the field survey to derive the proposed development elements for the digital transformation system. In order to achieve the objectives of the study, the study community consists of all stakeholders and planners of tourism and travel activity in government tourism authorities, marketing and tourism managers in travel agencies, as well as some official in charge of the Ministry of Tourism and Antiquities, who have specialized information of the study, in addition to experts in the field of information and communication technology. A simple random sample of 150 individuals was selected from the study population. A questionnaire was used to collect data from the study sample members and the results showed that the majority of the opinions of the study sample members see the importance of having the infrastructure and basic strategies necessary to implement Digital transformation and working to spread targeted digital services in tourism institutions, in addition to the importance of working to remove the difficulties facing the application of digital transformation in Egyptian tourism and the development of tourism product. 